\title{
Online Education and Its Effective Practice: A Research Review
}

\author{
Anna Sun and Xiufang Chen \\ Rowan University, Glassboro, NJ, USA
}

sunq@rowan.edu Chenx@rowan.edu

\begin{abstract}
Using a qualitative content analysis approach, this study reviewed 47 published studies and research on online teaching and learning since 2008, primarily focusing on how theories, practices and assessments apply to the online learning environment. The purpose of this paper is to provide practical suggestions for those who are planning to develop online courses so that they can make informed decisions in the implementation process. Based on the findings, the authors argued that effective online instruction is dependent upon 1) well-designed course content, motivated interaction between the instructor and learners, well-prepared and fully-supported instructors; 2) creation of a sense of online learning community; and 3) rapid advancement of technology. In doing this, it is hoped that this will stimulate an on-going discussion of effective strategies that can enhance universities and faculty success in transitioning to teach online. Under current debates on the cost and quality of higher education, this study could help for the improvement of higher education and student enrollment and retention.
\end{abstract}

Keywords: online education, online teaching, online learning community, asynchronous learning, cognitive presence, social presence, teaching presence, online higher education

\section{Introduction}

Education can become transformative when teachers and students synthesize information across subjects and experiences, critically weigh significantly different perspectives, and incorporate various inquiries. Educators are able to construct such possibilities by fostering critical learning spaces, in which students are encouraged to increase their capacities of analysis, imagination, critical synthesis, creative expression, self-awareness, and intentionality. A byproduct of fostering such new approaches has been the creation of online courses developed in the United States and worldwide at exponential speed. It is becoming increasingly common at many higher education institutions, offering fully online and/or hybrid/blended courses combining online instruction with

Material published as part of this publication, either online or in print, is copyrighted by the Informing Science Institute. Permission to make digital or paper copy of part or all of these works for personal or classroom use is granted without fee provided that the copies are not made or distributed for profit or commercial advantage AND that copies 1) bear this notice in full and 2) give the full citation on the first page. It is permissible to abstract these works so long as credit is given. To copy in all other cases or to republish or to post on a server or to redistribute to lists requires specific permission and payment of a fee. Contact Publisher@InformingScience.org to request redistribution permission. face-to-face teaching. Statistics done by the Pew Research Center (2011) show that in the 2010-11 academic year, 89 percent of four-year colleges and universities offered courses taught fully online, or hy$\mathrm{brid} / \mathrm{blended}$ online, or other forms of distance/non-face-to-face instruction (Parker, Lenhart, \& Moore, 2011). Of all students enrolled in higher education in 2013, 32 percent took at least one online course (Allen \& Seaman, 2013). 
The development of online courses in higher education doesn't happen overnight. The 2008 study by the National Center for Educational Statistics (NCES) found that the main factors influencing higher-education institutions to offer online courses included meeting students' demands for flexible schedules (68\%), providing access to college for students who would otherwise not have access (67\%), making more courses available (46\%), and seeking to increase student enrollments (45\%) (Parsad, Lewis, \& Tice, 2008).

Distance education originated in the United States in the 1800's when teachers and learners at the University of Chicago, who were at different locations, tried to connect through correspondence programs (Mclsaac \& Gunawardena, 1996). Years later, the development of radio as a communication medium during World War I opened the door for using that technology for distance education in colleges and schools such as School of the Air established in Wisconsin in the 1920s (Mclsaac \& Gunawardena, 1996). With the popularity of television in the 1950s, visual instruction became possible for the first time between teachers and students who were not in the same locations. As computer and emailing technology blossomed in the 1970s and 1980s, distance education began to expand dramatically. The first fully online course was offered in 1981, and the first online program was established by the Western Behavior Sciences Institute in the following year (Harasim, 2000). In the mid-1980s, the first online undergraduate and graduate courses were initiated by several universities and schools. In the late $1980 \mathrm{~s}$, due to a shortage of teachers on math, science, foreign languages, etc., some K-12 schools turned to commercial courses offered through the then-new satellite technology, which greatly spurred still faster growth of distance education (Mclsaac \& Gunawardena, 1996).

The advent of the World-Wide Web (WWW) in 1991 was a powerful catalyst for moving distance education forward, and was a milestone in the rapid expansion and growth of online teaching and learning. Maloney-Krichmar and Abras (2003) stated that WWW "facilitated the widespread use of web sites and the development of online community groups supported by web pages and various forms of communications software" (p.4). Since then, colleges and universities both in the United States and around the world have offered not only just online courses but entire degree programs online as well (Wallace, 2003).

Ever since the severe economic crisis of 2008, federal and state funding for education in the United States has been declining. As a result of the high levels of austerity, more and more universities and colleges appear to have shown increasing interest in online education. How has online education evolved? Has it been successful? In what ways has it been proven effective? And what still remains to be done to achieve greater success in teaching and learning in an online environment? These questions have motivated us to conduct this study - reviewing research and studies on online education. At present, fewer studies on online education have focused on examining previous research and studies, and we have conducted a comprehensive review study trying to provide a platform of discussions for educators and policy makers on how to develop and deliver effective online programs.

There have been many vigorous debates and thorough studies on the differences between online and face-to-face classroom teaching, which however is not a focus of this study. Instead, this study's focus is on examining the positive aspects and strategies of the online learning and teaching process and how it has been implemented successfully. The goal here is to provide best practices for those who are planning to develop online courses to make informed decisions in the implementation process. In doing this, it is hoped that this will stimulate an on-going discussion of effective practices that can enhance universities and faculty success in transitioning to teach online. 


\section{Methodology}

\section{Research Design}

The research methodology for this study was to review published studies and research on online teaching and learning, the range of which included literature reviews prior to 2008 and empirical research after 2008. For purposes of this study, online education is operationally defined as a format used in learning when learners do not need to be in bricks-and-mortar classrooms. The terms online learning, online teaching, online education, online instruction, and online courses are used interchangeably throughout the article.

\section{Selection Criteria and Sources of Data}

The primary literature sources were journal articles and full texts. Because of our intent to examine the evolution of online education and how it was affected in the years following the 2008 economic crisis, a three-stage literature search was conducted, beginning with the literature reviews prior to 2008 as a foundation of our study in Stage I. Then, using the descriptors online teaching, online learning, and online instruction in stage II, we searched through empirical studies published since 2008. Informed by our initial findings from Stage II, we expanded our search descriptors in Stage III to include online course and instruction; cyberspace courses and instruction; computer-based courses and instruction; e-learning, teaching and instruction; web-based teaching, learning, and instruction; Internet teaching and instruction; tele-courses, tele-teaching, and tele-instruction; and virtual learning, teaching and instruction. The major sources we used for data collection were online databases including ERIC, EBSCO, PsycINFO, ContentFirst, Google Scholar, SAGE Online, Project Muse, Education Full Text, and Academic Search Premier. Based on the selection criteria of this study, 47 articles were chosen to answer our research questions: (1) How has online education been evolved? (2) What are the evidence-based effective practices in online teaching? And (3) what are the evidence-based effective practices in online learning? It is noted that education is about teaching and learning and it is also true what is effective in teaching might be equally applicable in learning. Because of the unique nature of online education, we intended to propose the second and third research questions in a way that both students' and teachers' perspectives on the effectiveness of online education can be addressed and emphasized.

\section{Data Analysis}

During our initial review of the literature, we began to note themes of online education emerge. We categorized the themes adhering to the theoretical framework developed by Garrison and his colleagues, which emphasizes social presence, teaching presence, and cognitive presence in online teaching and learning (Garrison, Anderson, \& Archer, 2000). Ultimately, we organized the findings into three major themes to answer our research questions, which included the evolution of online education, effective online teaching, and effective online learning. The qualitative content analysis approach (Cavanagh, 1997) was thus employed for the data analysis.

\section{Findings}

\section{How Has Online Education Been Evolved?}

\section{What do we know about online education?}

With the development of online education over time, its definition has been evolved. Regarding the aspects of the conversion from face-to-face classrooms to online, McIsaac and Gunawardena 
(1996) defined distance education as "no more than a hodgepodge of ideas and practices taken from traditional classroom settings and imposed on learners who just happen to be separated physically from an instructor" (p.5). Regarding the aspects of technology and organization, Moore and Kearsley (2012) defined that "distance education is teaching and planned learning in which teaching normally occurs in a different place from learning, requiring communication through technologies as well as special institutional organization" (p.2). Regarding the aspects of being distant, Finch and Jacobs (2012) defined it as "all forms of teaching and learning where the student and instructor are separated geographically and temporally" (p.546). It is noted that there is the purported need for conceptualizing distance education in rapidly changing technology and exponentially growing online education, but its various aspects make it difficult to agree on just one definition and on what constitutes distance education in practice.

When asking "Why do we need distance education?" Moore and Kearsley $(2012$, p. 8) in their study identified the following reasons as to:

- increase access to learning and training as a matter of equity

- provide opportunities for updating skills of the workforce

- improve the cost effectiveness of educational resources

- improve the quality of existing educational structures

- enhance the capacity of the educational system

- balance inequalities between age groups

- deliver educational campaigns to specific target audiences

- provide emergency training for key target areas

- expand the capacity for education in new subject areas

- offer combination of education with work and family life

- add an international dimension to the educational experience

In discussing the best practices of online education, Finch and Jacobs (2012) stated these advantages: reducing the time and costs for travel; increasing opportunities to access and collaborate with expert professionals in a global range; providing students with flexibility to access courses at their convenience; and allowing adjustments to subjects and content need.

The fast development of the Internet and the World Wide Web (WWW) has produced numerous benefits to education. Online education provides potential opportunities to open up new markets for higher education institutions. Many adult learners may enjoy the flexibility when they have to balance work, study, and family responsibilities. The wide range of various technology advancement used by universities' online programs may enhance the interaction between students and instructors, and among students at large (Bell \& Fedeman, 2013). In addition, the nature of the anonymity in the online environment may allow more students, who otherwise do not want to attend face-to-face classes because of their shy personality, to participate in online education where they do not physically see each other. Finally, the upgraded technology and software may allow instructors, students, and university administrators to collect data, feedback, and evaluation regarding their online experiences (Bell \& Fedeman, 2013).

In the research literature, online education is variously termed as "distance education" "elearning," "online learning," "blended learning," "computer-based learning," "web-based learning," "virtual learning," "tele-education," "cyber learning," "Internet-based learning," "distributed learning," etc. In this study we considered all of these terms to be sufficiently synonymous and used them interchangeably throughout this article. 


\section{Influence of technology and evolution of online course}

In online education, learning is asynchronous or synchronous or a combination of both. Asynchronous learning is teaching and learning that do not happen at the same time (Moore \& Kearsley, 2011), while synchronous learning refers to teaching and learning that happen at the same time, both of which are conducted through technologies such as Internet. When online education began in the late $20^{\text {th }}$ century, most online programs and classes were synchronous and used chat rooms, instant messaging, and texting. Both chat rooms and instant messaging, being synchronous, allow users to decide who participates in the conversation. The invention of @ symbol in 1972 for use in email (Maloney-Krichmar \& Abras, 2003), and the advent of the World Wide Web (WWW) in 1991 for the Internet connectivity (Harasim, 2000) have been the latest adapted by online education. The universal use of web sites has provided opportunities for the development of online communities and groups. Emailing, conferencing, chatting, working together via Google drive, Google doc, Google hangout, dropbox, facebook, Twitter, etc. have been widely used in online classrooms.

Online education can be categorized by its users: 1) University-Based Online Education, whose users are individuals enrolled in universities for the purpose of obtaining degrees and diplomas; 2) Massively Open Online Courses (MOOC) (some termed Massively Open Online Class), whose users are self-motivated individuals and whose programs are based on their learning goals, prior knowledge and skills, and similar interests (McAuley, Stewart, Siemens, \&Cormier, 2010; Schroeder, 2012). In general, students in the United States enroll in universities where online course formats have been added to already-existing classroom-based courses. At those institutions two modes of online classes are usually offered - fully online courses (not taught in bricksand-mortars classrooms), and blended/hybrid courses (a combination of face-to-face and webbased and technology-oriented format). Students in these two modes of online programs are granted credits, degrees, and certificates when they complete required courses and internships.

To increase the accessibility to higher education by larger segments of the public, the model of Massively Open Online Course (MOOC) was introduced in 2008, which includes universitybased and corporate-based online offerings. The university-based offering was initiated by Ivyleague higher education institutions, including edX in 2012 by Harvard University and the Massachusetts Institute of Technology (MIT), eduMOOC in 2011 by University of Illinois Springfield, Coursera in 2012 by the joint efforts of five universities (Princeton, Stanford, California/Berkeley, Michigan-Ann Arbor, and Pennsylvania), etc. Most of these are open to the public free of charge, which shows the universities' efforts to encourage the public to participate in online education.

Corporate-based online offerings, free or for-profit, were initiated mostly by organizations, corporations, and individuals. Following his resignation from Stanford University, Sebastian Thrun opened up a for-profit online initiative called Udacity in 2011. According to its website, it "offers a range of certification options that are recognized by major technology companies who are actively recruiting from the Udacity student body" (Udacity, 2015). Peer 2 Peer University (P2PU) is an online-education offering operated by volunteers who teach all courses. According to its website $<$ https://www.p2pu.org/en/ $>$, it is open and free to the public, which "not only helped learners feel confident about taking an online course, but our retention rates were also higher than in most online learning courses". Initiated by the Saylor Foundation in 2008, Saylor.org is a collection of college-level courses, free and open to the public. According to its website, Saylor.org Academy "is founded not just on open educational resources and open source learning technologies, but also on open access to credentials, and ongoing open learning opportunities" (Saylor Academy, 2015). 
Table 1 lists some popular online education initiatives. Although these initiatives are booming exponentially, the debate remains about whether corporate-based online-education initiatives have the credentials to grant credits and degrees to individual learners who have completed their online courses (Schroeder, 2012).

Table 1 -- Some Popular Online Education Initiatives

\begin{tabular}{|c|c|c|c|}
\hline Name & Sponsor & $\begin{array}{c}\text { Year } \\
\text { founded }\end{array}$ & Fees \\
\hline Coursera & $\begin{array}{l}\text { Joint efforts by Princeton University, Stanford Universi- } \\
\text { ty, University of California Berkeley, University of } \\
\text { Michigan-Ann Arbor, \& University of Pennsylvania }\end{array}$ & 2011 & Private \\
\hline eduMOOC & University of Illinois Springfield & 2011 & Free \\
\hline edX & Harvard University \& MIT & 2012 & Non-profit \\
\hline iTunes $\mathbf{U}$ & Apple Corporation & 2012 & For-profit \\
\hline $\begin{array}{l}\text { Khan } \\
\text { Academy }\end{array}$ & Salman Khan (Hedge Fund manager) & 2007 & Non-profit \\
\hline Minerva & $\begin{array}{l}\text { Minerva project and Keck Graduate Institute (KIG). } \\
\text { (Larry Summers, former Harvard University President } \\
\text { \& United States Secretary of the Treasury, chaired its } \\
\text { first advisory board) }\end{array}$ & 2012 & Private \\
\hline MITx & Joint efforts by Harvard University and edX & 2001 & Non-profit \\
\hline $\begin{array}{l}\text { Peer } 2 \text { Peer } \\
\text { University } \\
\text { (P2PU) }\end{array}$ & $\begin{array}{l}\text { Funding from the Hewlett Foundation \& the Shuttle- } \\
\text { worth Foundation, }\end{array}$ & 2009 & Non-profit \\
\hline Saylor & $\begin{array}{l}\text { Michael J. Saylor (Chairman, CEO, \& President of the } \\
\text { business intelligence company MicroStrategy) }\end{array}$ & 2008 & Non-profit \\
\hline TED-Ed & Sapling Foundation & 1984 & $\begin{array}{l}\text { Private } \\
\text { Non-profit }\end{array}$ \\
\hline Udacity & Sebastian Thrun & 2012 & For-profit \\
\hline Udemy & Eren Bali & $\begin{array}{l}\text { About } \\
2010\end{array}$ & $\begin{array}{l}\text { Some are } \\
\text { free; some } \\
\text { are for a } \\
\text { tuition fee }\end{array}$ \\
\hline $\begin{array}{l}\text { University } \\
\text { of the Peo- } \\
\text { ple }\end{array}$ & Shai Reshef (educational entrepreneur) & 2009 & Non-profit \\
\hline
\end{tabular}

Sources: Schroeder, 2012; official websites of individual initiatives

\section{What happened in online education prior to 2008 economic crisis?}

Two comprehensive reviews on online education offered pictures of the development of online education before 2008: Learning in Higher Education: A review of research on interactions 
among teachers and students by Wallace (2003) and Teaching Courses Online: A review of the research by Tallent-Runnels and her colleagues (2006). The Wallace review addressed two questions: 1) what constitutes teaching in online classes; and 2) what difference does the nature of subject matter make in online classes. She identified student roles in online education and how they perceived their online learning experiences. She reported that in online courses social presence and interaction were primary to student learning. In particular, she emphasized the importance of establishing an interactive relationship between students and instructor and among students, contending that such interactions led to satisfactory learning results. In addition, she questioned the effectiveness of the strategies to minimize transactional distance, and raised the concerns about the studies she reviewed, which were mostly evaluated by students' self-reports.

Pointing out that teachers' roles in online education have not been extensively examined, Wallace (2003) emphasized the crucial role teachers had in "facilitating discussion, providing direct instruction, and giving feedback to students" (p. 260). Future research, she suggested, should focus more on exploring "the relationship of teacher presence and immediacy to students' engagement in knowledge construction and to student learning" (p.260). She also reviewed ways to collaborate online to encourage students in creating a learning community by actively participating in the process, which, she stressed, was essential to the success of students' online learning. In addition, she raised several serious questions for future research, such as investigating whether an online learning community had any direct impact on students' learning outcomes.

In attempting to examine who uses online education and why they choose it, Tallent-Runnels and colleagues (2006) found that such learners were 1) mostly non-traditional students, who were older than normal college-age students; 2) were highly motivated, goal-oriented, and determined to achieve good learning outcomes from online education; and 3) normally had important roles in their local communities. After reviewing 76 studies on online teaching, Tallent-Runnels and colleagues (2006) examined the course environment and proposed findings similar to Wallace's (2003) on the benefits of creating an online learning community that fostered small discussion groups and effective communication methods. In such a process, they emphasized, teaching presence was highly important because immediate feedback and responses from instructors were critical to students' learning - a factor that contributed to students' satisfaction with their courses. Although they agreed on the importance of instructor-student interactions, they noted that because of the relatively small samples of participants in most studies they reviewed, it was necessary to be cautious about generalizing research results when applied to a larger population. They pointed out that so far no empirical studies were able to illustrate the online learning was more effective than the face-to-face mode - or vice versa.

While convenience might be a major factor for students to choose online education, other factors remain such as the quality of the course design, the creation of interaction, and evaluation system (Tallent-Runnels et al., 2006). In addition, Tallent-Runnels and colleagues (2006) listed important components - the learners' characteristics, the course delivery system, specific instructional tools, and the instructors - for the success of online education. At the same time, they suggested that to support online education, universities train faculty and students, provide the adequate technical support, give the faculty the release time for the online course development, etc. They also recommended that future research should address the following: (1) online instruction and learning; (2) ways to improve online interaction to meet various students' learning styles; (3) ways to relate learners' outcomes to online delivery system variables, to learning theories and research, and to various models of the course design; (4) improvement of the design and management of online discussions; and (5) the cost effectiveness of online courses. Our study was guided by the recommendations of these two comprehensive reviews, and their recommendations were taken into consideration in our study on online education in the post-2008 era. 


\section{What are the impacts of the $\mathbf{2 0 0 8}$ economic crisis on online education?}

Despite all the calls for improvements in higher education and lowering the cost, focus has been elsewhere. Washington, of late, has been more preoccupied with "political theater" involving manufactured crises such as the hassle over raising the country's debt ceiling, the conflict over budgetary sequestrations, the confrontation that led to the government shutdown, and the vigorous battle over the Affordable Care Act. In particular, the economic crisis degraded the U.S. economy in 2008, and the fragile U.S. economy has had great impacts on higher education in general, and on online education in particular. The largest complaint has been the budget cut on higher education. However, the economic downturn seemed good to online education. Allen and Seaman (2013) found in their survey that about three quarters of the institutions reported enrollment increase in their online courses and programs following the financial crisis. In the two years following the crisis, they reported, the demand for online courses exceeded that for face-to-face formats. The reason for such an increase, they think, is twofold: 1) the lack of good jobs during the downturn caused more people to seek education; 2) due to the competition in workplaces, employed people sought education in order to improve and advance themselves. In 2013, about 6.7 million (32 percent) students took at least one online course at a higher education institution (Allen \& Seaman, 2013).

\section{What Has Been Proved Effective in Online Teaching?}

\section{Cognitive and teaching presence}

Using Dewey's concept of reflective thinking in the generalization of education, Garrison and colleagues (2000) postulated that cognitive presence is a process in the Community of Inquiry (CoI) where participants construct, explore, resolve, and confirm meanings through collaboration and reflection. In such a process, question remains on how to transfer the inquiry to the resolution. Keengwe and Kidd (2010) identified the cognitive tasks as "responding to questions; editing questions and responses; thinking, reasoning, and analyzing information; and helping students to engage in rehearing and retrieving information in the process of delivering online courses" (p.6). Based on his online teaching experience and action research, Petlz (2008) explained at great length how to integrate facts, concepts, theories, and knowledge into learning and discussions in the development of cognitive presence, with strong emphasis on the importance of the source, clarity, accuracy, and comprehensiveness of knowledge in demonstrating cognitive presence.

Nine years later, after introducing the three presences - social presence, cognitive presence, teaching presence - as primary elements for successful online education, Garrison, Anderson, and Archer (2009) further examined the nature and quality of cognitive presence by analyzing asynchronous text-based computer conference transcripts. Employing the theory of critical thinking, they argued that its outcome can be best judged by practical inquiry that included a triggering event, exploration, integration, and resolution. The triggering event is the first inquiry at which point a problem or an issue is identified for further investigation. The second inquiry is exploration where learners examine, by means of reflection, discourse, issues or problems. The next step is integration, in which learners continue to examine what they have learned from exploration and develop ideas and construct meanings. The final step is resolution where a definite result is determined and the new knowledge is applied (Garrison et al., 2009; Garrison \& Arbaugh, 2007; Kupczynski, Wiesenmayer, \& McCluskey, 2010). The study by Garrison and his colleagues (2009) provides a reliable tool for assessing cognitive presence and the cognitive nature of teaching and learning in an asynchronous, text-based environment. The results of the study have instilled confidence in researchers that higher-order learning in online-education environment can be accomplished through facilitating cognitive presence (Garrison et al., 2009). 
On the other hand, Ke (2010), in his study of online adult learning, pointed out that cognitive presence in adult learners was about how they perceived their learning satisfaction. His study showed that "most adult students reported deep learning as the dominant learning approach" (p.814). He discussed individualistic learning as a dominant approach in adult learners' cognitive learning activities, indicating that adult learners had mixed feelings about online discussions. In their view, the effectiveness of online discussion largely depended on who participated in the discussion, and meaningful and valuable discussion were grounded on whether the participating peers were "chatty and talkative." They were concerned that unbalanced discussion performances among their peers would greatly undermine the quality of online discussion.

Viewing teaching presence as a significant factor to successful online education, Garrison and his colleagues (2009) explored constructs of teaching presence, including instructional design, discourse facilitation, and direct instruction. Instructional design focused on planning, structuring, processing, interacting, and evaluating online courses. Its activities include, but are not limited to, creating online presentations, lectures notes, audio/video mini-lectures, individual or group activity assignments with scheduled deadlines, and providing guidance on how to use the technology on the course website (Garrison et al., 2009; Garrison \& Arbaugh, 2007; Kupczynski et al., 2010). The discourse facilitation consisted of instructors engaging students in content materials, reviewing and responding to students' posts, asking questions or expressing observations pertaining to students' discussions, keeping course discussions moving in the right direction, interacting with individual students who need extra instructions and attention (Coppola, Hiltz, \& Rotter, 2002; Kupczynski et al, 2010). For the direct instruction, the instructor provided intellectual and scholarly leadership, which may include judging whether students understand certain content, providing additional resources and information about the course, offering timely feedback on students' discussions, and motivating them toward higher-order learning and knowledge (Coppola et al, 2002; Kupczynski et al, 2010; Shea, Swan, Li, \& Pickett, 2005).

Pelz (2008), drawing upon his action research, has itemized steps that instructors and students can contribute to facilitate the discussion, including (a) identifying areas of agreement and disagreement; (b) seeking to reach consensus/understanding; (c) encouraging, acknowledging, and reinforcing students' contributions; (d) setting a climate for learning; (e) drawing in participants/prompting discussion; (f) assessing the efficacy of the process (p. 114). In addition, Pelz itemized what should be included in the process, such as (a) presenting contents and questions; (b) focusing the discussion; (c) summarizing the discussion; (d) confirming understanding; e) diagnosing misperceptions; (f) injecting knowledge from diverse sources; g) responding to technical concerns (p.114). Ke (2010) in his study of adult learning emphasized the importance of online design for course sites, contents, online discussions, online evaluations, and interfacing.

An online learning community provides a potential environment that enables students to learn effectively through the growth of teaching, cognitive, and social presence. (Social presence is briefly defined as students' participation.) Each presence has a distinctive role to play, but they are intertwined and interchangeable. Teaching presence is essential to balance cognitive and social presence (Garrison et al. 2000). Ke's (2010) qualitative and quantitative findings indicated that teaching presence plays the central role and "that teaching presence should be the catalyst that initiates the community development process" (p.818). However, he raised his concerns on the online discussion for adult learners with regard to cognitive presence, arguing that online discussion injected ambiguity in the reinforcement of cognitive presence and should be evaluated further using multiple data resources and methodologies. To online learners, cognitive presence and epistemic engagement can occur only when teaching and social presence are well developed, and the development of social presence is dependent on how well the teaching presence has been established. He also pointed to the correlation between cognitive and social presence, suggesting 
that "the adult students with a stronger sense of community tend to have a higher level of learning satisfaction" (Ke, 2010, p. 819).

\section{Pedagogical practice for effective online teaching}

Interviewing 15 online instructors, all of whom had received South Dakota Board of Regents' ELearning Award, Bailey and Card (2009) addressed the importance of setting course goals, learning objectives, and expectations. These awardees shared eight pedagogical practices that they considered to be highly effective in practice: (1) fostering relationships; (2) engagement; (3) timeliness; (4) communications; (5) organization; (6) technology; (7) flexibility; and (8) high expectations (p.154). In their view, fostering good relationships and communication between instructors and students was crucial and can be achieved by instructors' empathy for students, passion for teaching, and willingness to help students succeed. Recognizing the very nature of communication in the online environment, these online instructors suggested that online instructors be attentive, responsive, and timely in responding to emails and text messages. To do so, their practical strategies included "giving timely feedback on completed assignments, responding to written questions, communicating requirements, and informing students when they will be away" (Bailey \& Card, 2009, p.154).

These online instructors also identified the need to engage their students, which can be accomplished by utilizing emails and online discussion boards, responding promptly to discussion questions, encouraging students to share their backgrounds and work experiences, and conducting meaningful small group projects. To achieve these objectives, they suggested online instructors be good organizers. In a well-organized course they described, students should be given all course materials at the beginning of the class, be provided with direct links to the necessary websites and resources, and be clearly informed about how to navigate the university website to successfully complete the course. In addition, they noted that being flexible was another crucial element for effective online teaching. Technology isn't always perfect and reliable, and online instructors have to be prepared to cope with issues such as system delays, software updates, email glitches, etc. Good online instructors are those who possess the knowledge and skills on how to use and adapt updated technologies, who are available online at all times, who frequently check for emails and text massages, who promptly reply to questions and concerns, and who grade and return assignments with feedback on a timely manner (Bailey \& Card, 2009).

\section{Online course design, instructions, and supports}

The course design process has five phases: (1) designing content; (2) developing content; 3) implementing content; 4) evaluating the course; 5) revising content (Keengwe \& Kidd, 2010). Examining the features and principles of Universal Instructional Design (UID) and Universal Design for Learning (UDL), Rao and Tanners (2011) advised instructors designing courses to consider not only the course objectives, but also how to adapt strategies and technologies for achieving the objectives. They highlighted several strategies that students appreciated most in their online learning. Uppermost among the students' preferences were the wide range of options and choices the online course provided. They found, for instance, that if the instructor's course design presented materials in various formats - using videos, audios, other technologies or software - that can make required text-based materials more interesting and can also allow students to respond in multiple formats as well.

Another element favored highly by students was strategic instructions (Rao \& Tanners, 2011). As a common phenomenon, a large number of online students are non-traditional with full-time jobs and families, who have decided to seek continuing education for personal advancement in their fields. They want courses that are well designed and can enhance the possibilities for them to complete courses successfully, such as the clarity of the assignments and feedback that is con- 
sistent and timely. With instructor-student interactions being the key to successful online education, the more often those connections occur, the more engaged the students are in their courses (Rao \& Tanners, 2011).

Brindley, Blaschke, and Walti (2009) outlined more strategies in great details, including facilitating learner readiness for group work; providing scaffolding for developing skills; establishing a healthy balance between structure (clarity of task) and learner autonomy (flexibility of task); nurturing the establishment of learner relationships and a sense of community; monitoring group activities actively and closely; making group tasks relevant for learners; choosing tasks that can be best suited for being performed by a group; and providing sufficient time for collaborative learning activities.

Studies have indicated that it takes more time to teach online courses than that of traditional courses (Crawford-Ferre \& Wiest, 2012; Gabriel \& Kaufield, 2008). Keengwe and Kidd (2010) concurred, noting that "online delivery is more labor intensive because of the amount of time required to grade papers and respond to questions" (p. 4). Therefore, online instructors "need additional support in the form of reduced teaching loads or provision of teaching assistance" and that "most instructors new to online teaching begin with little to no training or preparation specific to this deliver mode" (Crawford-Ferre \& Wiest, 2012, p. 13).

For online education to be effective, having a high-quality faculty is crucial. Crawford-Ferre and Wiest (2012) suggested that online faculty have professional development and sufficient professional training related to the online design and instructions. Professional development should emphasize how to promote effective online collaboration for students, how to set high expectations, how to adjust instructors' teaching to conform to the online environment, and how to create proper online teaching strategies, etc. In addition, online faculty also need the adequate training in the technologies applicable to online teaching: how to use the online system and course software, knowing what to do and whom to call when certain technology problems occur, etc. (Crawford-Ferre et al., 2012). Studies, however, have found that most online faulty have not received adequate training and support from their institutions (e.g. Crawford-Ferre \& Wiest, 2012; Gabriel \& Kaufield, 2008).

To enhance the quality of online teaching and learning, Keengwe and Kidd (2010) advised that online instructors have clear and structured strategies for setting up and managing, obtaining and utilizing required resources, charting the sequence of activities, structuring timelines, etc. Of all the tasks, they ranked direct instruction as a top priority, emphasizing the importance of the faculty role. Other top priorities included (1) curriculum setting up and development; (2) course design that utilizes content such as PowerPoint lecture notes, reflective personal insights, minilectures, etc.; (3) design and facilitation of meaningful group and class activities; (4) establishment of schedules and timelines for required assignments; (5) providing guidelines and strategies enabling students to properly use the technologies related to online learning. The research team also pointed out that online instructors need to balance pedagogy and technology in designing and delivering course content (Keengwe \& Kidd, 2010).

\section{What Has Been Proven Effective in Online Learning?}

\section{Promoting social presence}

Social presence is a key component in online education and has a direct impact in many ways on the development of a learning community and interaction in online environments (Kehrward, 2008; Swan, Garrison, \& Richardson, 2009). The term social presence was created in 1976 by Short, Willams, and Christie, to describe social effects that are primarily influenced by the extent of individuals' participation in particular occasions. It is a communicator's sense of awareness of 
the presence of another individual through interaction (Short et al., 1976). In the context of online learning, social presence is defined as "the ability of participants in a community of inquiry to project themselves socially and emotionally, as 'real' people (i.e. their full personality), through the medium of communication being used" (Garrison et al, 2000, p. 94). Garrison and colleagues (2000) in their theoretical model identified three indicators of social presence - expression of emotion, open communication, and group cohesion. Considering the asynchronous nature of most online environments, it is necessary for online learners to develop social bonds, which enables them to feel secure and open to communicating with their peers. In such environments, social interaction and communication can grow and be sustained around a common goal and purpose among students themselves and between students and their instructors (Garrison et al., 2000).

Following a collective case study and interviews that were done by accessing online students' dialogical process, Kehrward (2008) defined social presence as "an individual's ability to demonstrate his/her state of being in a virtual environment" (p. 94), where individuals were willing to engage in exchanges and communications that were related to learning activities such as posting messages, responding to others, participating in the group work, etc. The nature of the social presence is that individuals are "being present" in the cyber environment to the extent that they are often visible and performative. Moreover, for individuals to develop a presence in an online environment, they have to demonstrate their abilities, their pursuits of opportunities, and their motivation to establish and maintain an ongoing participation (Kehrward, 2008).

Using qualitative and quantitative methodologies in a mixed-method case study, $\operatorname{Ke~(2010)~inves-~}$ tigated the dispositions of social presence for adult online students. In his view, it is crucial but not easy to develop "virtual relationships, virtual knowing, and virtual clique," and relationships developed among adult learners tend to be "those with similar working styles or those who were in a cohort group during the program of study" (p. 816). Adult learners who communicate via texts in an asynchronous environment find it a challenge to get to know a peer and uncomfortable to try to judge a peer by means of their posts. Also, adult learners experience the negative setbacks when they feel that "a group of friends could dominate online discussion, thus intimidating others who were newcomers" (Ke, 2010, p. 817). In such cases, it is difficult for social presence to be developed and maintained.

Yuan and Kim (2014) see both social and teaching presence as valuable influences in the development of a learning community. A high measure of social presence, they argue, "enhances learning interaction, fosters the development of critical thinking skills, improves learning performance, and leads to greater satisfaction with a course" (p.223). Teaching presence, on the other hand, is viewed as an important factor in balancing social and cognitive presence to improve learners' academic outcomes. Employing the factor analysis methodology, Shea and Bidjerano (2009) demonstrated that cognitive presence may be influenced by social presence with the level of comfort in online discussion, and "lower level of comfort with online discussion is strongly correlated with lower levels of cognitive presence. When students see their instructors taking an active role in fostering online discussions on relevant issues, they also report higher cognitive presence" (p. 551). Social presence, on the other hand, mediates teaching and cognitive presence (Swan et al, 2009).

\section{Interactivity, collaboration, and online learning community}

Many researchers have defined what a learning community looks like in an online environment and have stressed its importance from different perspectives. Yuan and Kim (2014) stated that a learning community was the creation of a sense of belonging by a group of learners, where learners trusted one another, constructed knowledge, shared useful information, established connections by getting to know one another, set up common objectives for learning, and believed that 
their needs would be fulfilled. Cox and Cox (2008) contended that asynchronous, threaded discussions can be effective in creating a collaborative learning environment as well as interpersonal and group dynamics.

Online learners benefit greatly from online learning communities in the following ways: (1) because of their connectivity with one another, they are able to share knowledge and fulfill common goals, which can reduce students' dropout rates; (2) the relationship and interaction between the instructor and learners and among peer learners can increase student performances and their satisfaction of the course; and (3) learners can receive supports and help from their peers, and at the same time they can add their knowledge base through their interactive actions (Yuan \& Kim, 2014). Yuan and Kim (2014) provided the following guidelines for the development of an online learning community:

- The effort to build a learning community should start at the beginning of a course and continue throughout the term.

- Both students and instructors should be involved in building the learning community.

- Asynchronous and synchronous technologies should be both used to create a shared space in which students and instructor interact.

- Various strategies should be employed to stimulate discussions.

- Both task-oriented discussions and social interactions should be encouraged.

- Students should be assigned tasks that require collaboration.

Numerous studies have illustrated the strong correlation between social interaction, sense of community, and their roles in achieving success in online learning (e.g., Brindley et al, 2009; Bryant \& Bates, 2015; Cox \& Cox, 2008; Ke, 2010; Sadera, Robertson, Song, \& Midon, 2009; Sher, 2009; Whipp \& Lorentz, 2009; Yang, Yu, Chen, \&Huang, 2014). Typically, there are three types of interaction: (1) student-instructor interaction; (2) student-student interaction; and (3) student-content interaction (Sher, 2009). The interactions between students and the instructor can be asynchronous or synchronous, with the instructors delivering the information, facilitating the learning, answering questions, and providing feedback. At the same time, individual students can take the initiative to ask questions or to contact the instructor for extra help or specific needs. The interactions among students provide them with a way to exchange information and ideas among themselves. This can occur between individual students, in group projects and group discussions, in case studies, etc., and can stimulate collaboration, the sharing of knowledge and skills, and student learning. The student-content interaction refers to the way that students get information and course materials, which can be in the form of texts, videos, audios, computer programs, web resources, etc. (Sher, 2009).

To ensure the establishment and growth of effective social interaction, Kehrwald (2008) has identified three pre-conditions - ability, opportunity, and motivation - which he says should be structured through design and facilitation that can "(a) promote productive interactions; (b) prevent learners from being overwhelmed by the demands of interaction within large groups; and (c) balance the needs for both flexibility and structure" (p.97). Based on their exploratory study of three online instructors, Whipp and Lorentz (2009) have suggested that to maintain effective interaction, instructors in online courses ask challenging questions, probe for elaboration and explanation, provide timely, clear, and concise responses to students' help-seeking, offer direction and guidance of discussions to prompt all students to participate, focus on specific issues in discussions, and summarize contents weekly. Furthermore, they observed effective online instructors were those who projected a strong social presence with frequent acknowledgements, timely feedbacks, friendly greetings, using first names, and expressions of emotion and empathy. In that way, instructors maintained a supportive learning environment by monitoring group dynamics, inviting students to seek help, and contacting non-participants. 
Based on a joint program by University of Maryland University College in the United States and University of Oldenburg in Germany, Brindlet et al. (2009) conducted a study on how to create effective small online learning groups. They argued that instructional strategies in online classrooms such as small group collaboration and learning were equally effective, if not more, as the assessment. Collective learning, they argued, can foster deeper learning and teamwork skills. Meanwhile, all participants in Kehrwald's qualitative study (2008) pointed out that text-based online messages can indicate a variety of clues about senders, such as personal history, personality, and current circumstances. The study participants expressed they preferred to have more prior knowledge of each other's cultures and backgrounds, and were more inclined towards in-depth individual conversations (Yang et. al., 2014). To establish such an interaction, trust and support are needed. In Wang's view (2014), building trust in an online environment was essential to the success of online education, and she identified the following meaningful and trust-inducing factors: prior positive experience, good reputation, high quality of information and design, contact details, instructor assertiveness, instructor responsiveness, a sense of care and community, and reliable and timely access.

\section{Discussion and Conclusion}

Online education is here and is highly likely to stay and grow. The review of its history clearly shows online education has developed rapidly, fueled by Internet connectivity, advanced technology, and a massive market. It has evolved from $19^{\text {th }}$ century correspondence programs to the $21^{\text {st }}$ century's vibrant and well-designed institutional online offerings. We can well anticipate that online education will continue to increase its presence and influence higher education through a vigorous process of reshaping, refining, and restructuring. It is unlikely, however, to replace traditional higher education but merely to be an alternative. But, owing to its flexibility, accessibility and affordability, online education is gaining in popularity, especially for people who are otherwise unable to obtain education because of physical distance, schedule conflicts, and unaffordable costs.

Throughout this study, the primary focus was to discuss how theories, practices and assessments apply to the online learning environment. It started with a basic overview of online education as studied and perceived by Garrison et al. (2000), which served as the theoretical framework for this study. We then examined how presented theories have applied to various aspects of online course design and development. We first examined the online environment over time, its evolvement, and the technologic impacts on online education. In online teaching, we focused our attention on the relationships between cognitive and teaching presences to determine the best and most desirable practices and strategies for online pedagogy. Within the realm of online learning, we directed our attention on the creation of an online learning community by means of promoting social presence, interactions, and collaboration between the instructor and students and among students.

\section{Implications from the Study}

Throughout the entire review study, we found that one of the primary challenges in online education is to develop a sense of community in the online environment. To establish such a community, several studies we reviewed pointed out the significance of promoting social presence, interaction, and collaboration (Brindley et al., 2009; Cox \& Cox, 2008; Kehrwald, 2009; Sher, 2009; Swan et al., 2009; Whipp \& Loentz, 2009; Yuan \& Kim, 2014). We thus argue that both learners and instructors have to make a joint effort to get deeply involved in constructing interaction and collaboration between the instructor and students and among students to create an effective online learning community. Recognizing that student-centered learning is the key in online education, we were disappointed to note that although many studies emphasized the importance of creating 
such a learning community, they lacked effective and detailed means, approaches, and technologies that could be used to achieve that objective.

This study reviewed the rapid advancement of technology and how it has greatly impacted on online education. It is almost certain that technology will continue to excel, and it is also almost certain that online teaching and learning will be greatly influenced by and changed along with it. Substantial evidence exists in our reviews that technology such as the invention of World Wide Web (WWW) and emails are instrumental for the rapid development of online education. On the other hand, we argue that the standardization and inflexibility of online products could become barriers to individualize teaching and learning. Although the reviewed studies did provide a variety of approaches on how instructors have adapted and changed their course curricula, designs, and instruction to the online environment, the individualized teaching and instructions have failed. Our review found that few studies were trying to explore how to progress toward online instructions that would be more adaptable to individual learners' needs.

This study went to great lengths discussing best practices and strategies for greater effectiveness in online teaching, including eight pedagogical practices designed to achieve that objective and what constitutes a well-organized online course. Wang (2014) in her comprehensive study on how to build trust in online education presented and analyzed 12 trust-inducing factors. In particular, giving a voice to disabled students on how this group perceived online learning and building trust, she tried to comprehend the views and challenges disabled students encountered when learning online. We applaud for Wang's study, but note that very few studies paid special attention to issues of disability, gender, ethnicity, culture, and language in online education.

Effective online instruction is dependent on well-designed course content, motivated interaction between the instructor and learners, well-prepared and fully supported instructors, etc. With our thorough analysis on this matter, this study further confirms that teachers definitely and indisputably play a crucial role in online education. They facilitate individual and group discussions, respond to student questions, design course assignments, and evaluate students' learning. Technology does not - and cannot - replace the role and position of the teacher. However, our review indicates that online faculty in higher education have not been receiving sufficient support from their respective institutions. It is a common practice that online instructors devoted more time and energy to online courses in comparison with their counterparts who teach in traditional classrooms. The reality is that they teach large numbers of students in their classes, receive little to no workload relief, get insufficient support from their universities with regard to recourses and technology, and have no professional development on online education.

\section{Recommendations}

It has become clear in the $21^{\text {st }}$ century that online education is entering mainstream and becoming a growing market as it continues to expand access to learning for more people (Gallagher \& LaBrie, 2012). Therefore, online instructors and students need to synthesize information across subjects to critically weigh significantly different perspectives and incorporate various inquiries. In doing so, they need to construct such possibilities by means of fostering critical learning spaces, where students are encouraged to increase their capacities of analysis, imagination, critical synthesis, creative expression, self-awareness, and intentionality in action. Only well-designed and effectively delivered online courses can survive to fulfill the possibility of blending the borders of the classrooms and to connect formal learning to broader space and vast social issues through an energetic online learning community.

In the end, education is about encouraging different ideas, various viewpoints, and a cacophony of voices. Online instructors are widely viewed as facilitators (e.g. Brindley et al., 2009; Crawford-Ferre \& Weist, 2012; Gabriel \& Kaufield, 2008; Keengwe \& Kidd, 2010; Rao \& Tanners, 
2011) who should foster a merger between diverse theories and live experiences. Instructors should encourage students to relate their discussions, assignments and group work to their own experiences, to the viewpoints of others, to subject matters, and to their own learning and work. Current, online education is mostly the model of one-size-fits-all standardized curriculum that ignores the needs of students (Saba, 2012), and a focus should be more on exploring how online offering could meet individual learners' needs and provide differentiated online instructions through the course design.

Also, more is needed to know about student online experiences and what motivates students to participate in online education. In the end, online education is about students - their learning, their academic outcomes, and much more. More knowledge about the online process and the people involved will enable online instructors and institutions to better design their courses, serve students' needs, and position themselves in a competitive global market. Ke (2010) in his study pointed out that "a group of friends could dominate online discussion, thus intimidating others who were newcomers" (p.817). Instructors should henceforth make great efforts to value the differences that exist within online classes regardless of race, gender, class, ethnicity, sexual orientation, learning ability, experiences, and socioeconomic status. A focus is needed to find ways to strive toward diversity to bridge differences, to close divides, and to facilitate to accomplish those in an online environment. Instructors should try to develop, facilitate, and promote an environment where all students are able to learn from one another.

Finally, online course instructors deserve more researchers' attention to explore their teaching journeys and professional development needs. As reported, a large number of the faculty in higher education were reluctant to teach online courses (Crawford-Ferre \& Weist, 2012), and those who have taught online courses reported that it took much more time teaching online classes than face-to-face mode (Keengwe \& Kidd, 2010). On the other hand, the misassumption is permeated that online teaching is easier than the traditional classroom teaching. Given the fact that online education is a new dynamic to both novice and veteran faculty, adequate professional development is necessary, which may include effective course design, instruction, implementation, and evaluation.

While this review was initiated with the authors' intention to design and teach online courses, drawing upon knowledge and information in the existing literature, the authors have sought to make a contribution to the field by discussing best practices and evidence-based effective strategies in online education. It might be useful to individual programs and instructors who want to develop online courses and individualize the course instructions and personalize the academic learning. The study might also be useful to the institutions that want to institutionalize online education in the era of the fast-growing technology and the intensified financial austerity. Individual institutions have their own vision and mission, and this study may make it possible for them to create innovations for teaching and learning.

\section{Future Research}

There can be little doubt that online education is destined to continue to grow, possibly at everfast speed. That being the likely case, more research should be conducted to investigate the effectiveness, efficacy, and improvement of online teaching and learning. At present time, however, there is a great gap and perhaps future research should be focused more on in-depth analysis of online instruction practices, step-by-step implementation, and the most effective practices for online course design and instruction. This article has reviewed aspects of how to teach effectively and successfully in an online learning environment. However, there is no empirical evidence in the reviewed studies and research to demonstrate whether online education has actually improved students' academic outcomes. Future research, therefore, may connect online education with students' academic achievements. 
Online education is a growing trend, and more and more institutions may eventually be offering more and more online courses to an increasing number of students. Therefore, future studies should be designed to obtain students' perspectives, especially those who are new to computerbased learning. In addition, the study may also focus on this regard by levels of students in online education such as undergraduate and graduate level and by subjects and disciplines.

Online education is an alternative for students' learning (Wang, 2014), which is intended to focus on critical thinking and creation. However, online courses are commonly dictated by the technology (Callaway, 2012; Cole, Shelley, \& Swartz, 2014) and are designed more for the convenience of the online system and the technology. To promote intellectual rigor and the development of informed and individual perspectives, further investigation should explore how to use technology and software to engage students in multiple and ongoing dialogues in a variety of online formats. Further research is needed to investigate how group designs can impact social interaction and the sense of a learning community considering group members' different personalities, learning styles and levels of skill. Previous studies mainly examined postings sent by participants. With the advancement of technology, researchers need to study the roles that a variety of technological tools play in promoting more effective social interaction and growth of a learning community, for example, audio and/or video conferencing via Google Hangout and Skype, social network media, and virtual reality environments.

\section{References}

Allen, I. E., \& Seaman, J. (2013). Changing course: Ten years of tracing online education in the United States. San Francisco, CA: Babson Survey Research Group and Quahog Research Group LLC.

Bailey, C. J., \& Card, K. A. (2009). Effective pedagogical practices for online teaching: Perception of experienced instructors. Internet and Higher Education, 12, 152-155.

Bell, B. S., \& Fedeman, J. E. (2013). E-learning in postsecondary education. The Future of Children, 23(1), $165-185$.

Brindley, J., Blaschke, L. M., \& Walti, C. (2009). Creating effective collaborative learning groups in an online environment. The International Review of Research in Open and Distributed Learning, 10 (3). Retrieved from http://www.irrodl.org/index.php/irrodl/article/view/675/1313

Bryant, J., \& Bates, A. J. (2015). Creating a constructivist online instructional environment. TechTrends, $59(2), 17-22$.

Callaway, S. K. (2012). Implications of online learning: Measuring student satisfaction and learning for online and traditional students. Insights to a Changing World Journal, 2. Retrieved from www.franklingpublishing.net

Cavanagh, S. (1997). Content analysis: Concepts, methods and applications. Nurse Researcher, 4(3), 5-16.

Cole, M. T., Shelley, D. J., \& Swartz, L. B. (2014). Online instruction, E-learning, and student satisfaction: A three year study. The International Review of Research in Open and Distance Learning, 15(6), 111131.

Coppola, N. W., Hiltz, S. R., \& Rotter, N. G. (2002). Becoming a virtual professor: Pedagogical roles and asynchronous learning networks. Journal of Management Information Systems, 18(4), 169-189.

Coursera. (2012). Retrieved from https://www.coursera.org

Cox, B., \& Cox, B. (2008). Developing interpersonal and group dynamics through asynchronous threaded discussions: The use of discussion board in collaborative learning. Education, 128(4), 553-565.

Crawford-Ferre, H. G., \& Wiest, L. R. (2012). Effective online instruction in higher education. The Quarterly Review of Distance Education, 13(1), 11-14. 
Finch, D., \& Jacobs, K. (2012). Online education: Best practices to promote learning. Proceedings of the Human Factors and Ergonomics $56^{\text {th }}$ Annual Meeting.

Gabriel, M. A., \& Kaufield, K. J. (2008). Reciprocal mentorship: An effective support for online instructors. Mentoring and Tutoring: Partnership in Learning, 16(3), 311-327.

Gallagher, S., \& LaBrie, J. (2012). Online learning 2.0: Strategies for a mature market. Continuing Higher Education Review, 76, 65-73.

Garrison, D. R., Anderson, T., \& Archer, W. (2000). Critical inquiry in a text-based environment: Computer conferencing in higher education. The Internet and Higher Education, 2(2-3), 87-105.

Garrison, D. R., Anderson, T., \& Archer, W. (2009). Critical thinking, cognitive presence, and computer conferencing in distance education. American Journal of Distance Education, 15(1), 7-23.

Garrison, D. R., \& Arbaugh, J. B. (2007). Researching the community of inquiry framework: Review, issues, and future directions. The Internet and Higher Education, 10, 157-172.

Harasim, L. (2000). Shift happens: Online education as a new paradigm in learning. Internet and Higher Education, 3, 41-61.

Keengwe, J., \& Kidd, T. T. (2010). Towards best practices in online learning and teaching in higher education. MERLOT Journal of Online Learning and Teaching, 6(2), 533-541.

Ke, F. (2010). Examining online teaching, cognitive, and social presence for adult students. Computers \& Education, 55, 808-20.

Kehrwald, B. (2008). Understanding social presence in text-based online learning environments. Distance Education, 2 (1), 89-106.

Kupczynski, L., Ice, P., Wiesenmayer, R., \& McCluskey, F. (2010). Student perceptions of the relationship between indicators of teaching presence and success in online course. Journal of Interactive Online Learning, 9(1), 23-43.

Maloney-Krichmar, D., \& Abras, C. (2003). History of emergence of online communities. In K. Christensen \& D. Levinson (Eds.), Encyclopedia of community: From village to virtual world. Thousand Oaks: Sage Publication, 1023-1027.

McAuley, A., Stewart, B., Siemens, G., \& Cormier, D. (2010). The MOOC model for digital practice. Retrieved from http://www.elearnspace.org/Articles/MOOC_Final.pdf

Mclsaac, M. S., \& Gunawardena, C. N. (1996). Distance education. In D. H. Jonassen (Ed.), Handbook of research for educational communication and technology: A project of the Association for Educational Communication and Technology (pp.403-437). New York: Simon \& Schuster Macmillan.

Moore, M., \& Kearsley, G. (2012). Distance education: A systems view of online learning (3rd ed.). Belmont, CA: Wadsworth.

Parker, K., Lenhart, A., \& Moore, K. (2011). The digital revolution and higher education: College presidents, public differ on value of online learning. Washington D.C.: Pew Research Center.

Parsad, B., Lewis, L., \& Tice, P. (2008). Distance education at degree-granting postsecondary institutions: 2006-07. Washington D.C.: National Center for Education Statistics Institute of Education Sciences.

Pelz, B. (2008). (My) three principles of effective online pedagogy. Journal of Asynchronous Learning Networks, 14(1), 103-16.

Rao, K., \& Tanners, A. (2011). Curb cuts in cyberspace: Universal instructional design for online courses. Journal of Postsecondary Education and Disability, 24(3), 211-229.

Saba, F. (2012). A systems approach to the future of distance education in colleges and universities: Research, development, and implementation. Continuing Higher Education Review, 76, 30-37.

Sadera, W. A., Robertson, J., Song, L., \& Midon, M. N. (2009). The role of community in online learning success. Journal of Online Learning and Teaching, 5(2), 277-284. 
Saylor Academy. (2015). Retrieved from http://www.saylor.org/

Schroeder, R. (2012). Emerging open online distance education environment. Continuing Higher Education Review, 76, 90-99.

Sher, A. (2009). Assessing the relationship of student-instructor and student-student interaction to student learning and satisfaction in web-based online learning environment. Journal of Interactive Online Learning, 8(2), 102-120.

Shea, P.A., Swan, K., Li, C. S., \& Pickett, A. (2005). Developing learning community in online asynchronous college courses: The role of teaching presence. Journal of Asynchronous Learning Networks, 9(4), 59-82.

Shea, P., \& Bidjerano, T. (2009). Community of inquiry as a theoretical framework to foster "epistemic engagement" and "cognitive presence" in online education. Computer and Education, 52, 543-553.

Short, J., Williams, E., \& Christie, B. (1976). The social psychology of communication. New York: John Wiley.

Swan, K., Garrison, D. R., \& Richardson, J. (2009). A constructivist approach to online learning: The community of inquiry framework. In C. R. Payne (Ed.), Information technology and constructivism in higher education: Progressive learning frameworks (pp. 43-57). Hershey, PA: IGI Global.

Tallent-Runnels, M. K., Thomas, J. A., Lan, W. Y., Cooper, S., Ahern, T. C., Shaw, S. M., \& Liu, X. (2006). Teaching courses online: A review of the research. Review of Educational Research, 76(1), 93135.

Udacity. (2015). Retrieved from https://www.udacity.com/

Wallace, R. (2003). Online learning in higher education: A review of research on interactions among teachers and students. Education, Communication \& Information, 3(2), 241-280.

Wang, Y. D. (2014). Building student trust in online learning environment. Distance Education, 35(3), 345359.

Whipp, J. L., \& Lorentz, E. R. A. (2009). Cognitive and social help giving in online teaching: An exploratory study. Educational Technology Research and Development, 57, 169-192.

Yang, J., Yu, H., Chen, S. J., \& Huang, R. (2014). Strategies for smooth and effective cross-cultural online collaborative learning. Educational Technology \& Society, 17(3), 208-221.

Yuan, J., \& Kim, C. (2014). Guidelines for facilitating the development of learning communities in online courses. Journal of Computer Assisted Learning, 30, 220-232. 


\section{Appendix}

Summary of Reviewed Articles

\begin{tabular}{|c|c|c|c|c|}
\hline $\begin{array}{l}\text { Name of au- } \\
\text { thor \& year }\end{array}$ & Name of article & $\begin{array}{l}\text { Name of jour- } \\
\text { nal \& book }\end{array}$ & $\begin{array}{l}\text { Research } \\
\text { method }\end{array}$ & $\begin{array}{l}\text { *Brief summary of the find- } \\
\text { ings }\end{array}$ \\
\hline $\begin{array}{l}\text { Allen, I. E., \& } \\
\text { Seaman, J. } \\
(2013) .\end{array}$ & $\begin{array}{l}\text { Changing } \\
\text { course: Ten } \\
\text { years of track- } \\
\text { ing online edu- } \\
\text { cation in the } \\
\text { United States }\end{array}$ & $\begin{array}{l}\text { Babson Survey } \\
\text { Research } \\
\text { Group and } \\
\text { Quahog Re- } \\
\text { search Group } \\
\text { LLC }\end{array}$ & Quantitative & $\begin{array}{l}\text { The study addresses: Massive } \\
\text { Open Online Courses } \\
\text { (MOOC), is online learning } \\
\text { strategic, how many students } \\
\text { are learning online, does it } \\
\text { take more faculty time and } \\
\text { effort to teach online, are } \\
\text { learning outcomes in online } \\
\text { comparable to face-to-face, } \\
\text { has faculty acceptance online } \\
\text { increased, and barriers to } \\
\text { widespread adoption of } \\
\text { online learning. }\end{array}$ \\
\hline $\begin{array}{l}\text { Bailey, C. J., } \\
\text { \& Card, K. A. } \\
(2009) .\end{array}$ & $\begin{array}{l}\text { Effective ped- } \\
\text { agogical prac- } \\
\text { tices for online } \\
\text { teaching: Per- } \\
\text { ception of ex- } \\
\text { perienced in- } \\
\text { structors }\end{array}$ & $\begin{array}{l}\text { Internet and } \\
\text { Higher Educa- } \\
\text { tion }\end{array}$ & Qualitative & $\begin{array}{l}\text { From the interviews, the au- } \\
\text { thors found eight pedagogical } \\
\text { practices for effective online } \\
\text { teaching: fostering relation- } \\
\text { ships, engagement, timeli- } \\
\text { ness, communication, organ- } \\
\text { ization, technology, flexibil- } \\
\text { ity, and high expectations. }\end{array}$ \\
\hline $\begin{array}{l}\text { Bell, B. S., \& } \\
\text { Fedeman, J. } \\
\text { E. (2013). }\end{array}$ & $\begin{array}{l}\text { E-learning in } \\
\text { postsecondary } \\
\text { education }\end{array}$ & $\begin{array}{l}\text { The Future of } \\
\text { Children }\end{array}$ & Qualitative & $\begin{array}{l}\text { The study found during the } \\
\text { fall } 2010 \text { term } 31 \text { percent of } \\
\text { U.S. college students took at } \\
\text { least one online course. The } \\
\text { primary reasons for the } \\
\text { growth of e-learning in the } \\
\text { nation's colleges and univer- } \\
\text { sities include the desire of } \\
\text { those institutions to generate } \\
\text { new revenue streams, im- } \\
\text { prove access, and offer stu- } \\
\text { dents greater scheduling flex- } \\
\text { ibility. Yet the growth of e- } \\
\text { learning has been accompa- } \\
\text { nied by a continuing debate } \\
\text { about its effectiveness and by } \\
\text { the recognition that a number } \\
\text { of barriers impede its wide- } \\
\text { spread adoption in higher } \\
\text { education. }\end{array}$ \\
\hline
\end{tabular}




\begin{tabular}{|c|c|c|c|c|}
\hline $\begin{array}{l}\text { Brindley, J. } \\
\text { E., \& Walti, } \\
\text { C., \& } \\
\text { Blaschke, L. } \\
\text { M. (2009). }\end{array}$ & $\begin{array}{l}\text { Creating effec- } \\
\text { tive collabora- } \\
\text { tive learning } \\
\text { groups in an } \\
\text { online envi- } \\
\text { ronment }\end{array}$ & $\begin{array}{l}\text { The Interna- } \\
\text { tional Review } \\
\text { of Research in } \\
\text { Open and Dis- } \\
\text { tributed Learn- } \\
\text { ing }\end{array}$ & Qualitative & $\begin{array}{l}\text { This paper addresses whether } \\
\text { assessment makes a differ- } \\
\text { ence to the level of learner } \\
\text { participation and then con- } \\
\text { sidering other factors in- } \\
\text { volved in creating effective } \\
\text { collaborative learning } \\
\text { groups. It focuses on specific } \\
\text { instructional strategies that } \\
\text { facilitate learner participation } \\
\text { in small group projects, } \\
\text { which result in an enhanced } \\
\text { sense of community, in- } \\
\text { creased skill acquisition, and } \\
\text { better learning outcomes. }\end{array}$ \\
\hline $\begin{array}{l}\text { Bryant, J., \& } \\
\text { Bates, A. J. } \\
\text { (2015). }\end{array}$ & $\begin{array}{l}\text { Creating a } \\
\text { Constructivist } \\
\text { Online Instruc- } \\
\text { tional Envi- } \\
\text { ronment }\end{array}$ & TechTrends & Qualitative & $\begin{array}{l}\text { This paper describes the } \\
\text { ways in which social con- } \\
\text { structivist learning was fos- } \\
\text { tered in an online teacher } \\
\text { education program, and ex- } \\
\text { plores the potential of certain } \\
\text { online tools and methods to } \\
\text { facilitate a social constructiv- } \\
\text { ist approach to preparing } \\
\text { teachers in a virtual program } \\
\text { model. }\end{array}$ \\
\hline $\begin{array}{l}\text { Callaway, S. } \\
\text { K. (2012). }\end{array}$ & $\begin{array}{l}\text { Implications of } \\
\text { online learn- } \\
\text { ing: Measuring } \\
\text { student satis- } \\
\text { faction and } \\
\text { learning for } \\
\text { online and tra- } \\
\text { ditional stu- } \\
\text { dents. }\end{array}$ & $\begin{array}{l}\text { Insights to a } \\
\text { Changing } \\
\text { World Journal }\end{array}$ & Qualitative & $\begin{array}{l}\text { The purpose of the study was } \\
\text { to develop comprehensive } \\
\text { multidimensional measures } \\
\text { of satisfaction and motivation } \\
\text { factors, and to empirically } \\
\text { test a model of how motiva- } \\
\text { tion predicted student satis- } \\
\text { faction and learning. Results } \\
\text { showed that while traditional } \\
\text { students were satisfied both } \\
\text { with convenience and quali- } \\
\text { ty, as expected, online stu- } \\
\text { dents were unexpectedly not } \\
\text { satisfied with convenience, } \\
\text { but were satisfied with quali- } \\
\text { ty. Results also indicated that } \\
\text { quality satisfaction is not any } \\
\text { more strongly associated } \\
\text { with GPA than is conven- } \\
\text { ience satisfaction. }\end{array}$ \\
\hline
\end{tabular}




\begin{tabular}{|c|c|c|c|c|}
\hline $\begin{array}{l}\text { Cole, M. T., } \\
\text { Shelley, D. J., } \\
\text { \& Swartz, L. } \\
\text { B. (2014). }\end{array}$ & $\begin{array}{l}\text { Online instruc- } \\
\text { tion, E- } \\
\text { learning, and } \\
\text { student satis- } \\
\text { faction: A three } \\
\text { year study }\end{array}$ & $\begin{array}{l}\text { The Interna- } \\
\text { tional Review } \\
\text { of Research in } \\
\text { Open and Dis- } \\
\text { tance Learning }\end{array}$ & $\begin{array}{l}\text { Mixed- } \\
\text { method }\end{array}$ & $\begin{array}{l}\text { This article presents the re- } \\
\text { sults of a three-year study of } \\
\text { graduate and undergraduate } \\
\text { students' level of satisfaction } \\
\text { with online instruction at one } \\
\text { university. Overall, students } \\
\text { rated their online instruction } \\
\text { as moderately satisfactory, } \\
\text { with hybrid or partially } \\
\text { online courses rated as } \\
\text { somewhat more satisfactory } \\
\text { than fully online courses. } \\
\text { "Convenience" was the most } \\
\text { cited reason for satisfaction. } \\
\text { "Lack of interaction" was the } \\
\text { most cited reason for dissat- } \\
\text { isfaction. Preferences for hy- } \\
\text { brid courses surfaced in the } \\
\text { responses to an open-ended } \\
\text { question asking what made } \\
\text { the experience with online or } \\
\text { partially online courses satis- } \\
\text { factory or unsatisfactory. }\end{array}$ \\
\hline $\begin{array}{l}\text { Coppola, N. } \\
\text { W., Hiltz, S. } \\
\text { R., \& Rotter, } \\
\text { N. G. (2002). }\end{array}$ & $\begin{array}{l}\text { Becoming a } \\
\text { virtual profes- } \\
\text { sor: Pedagogi- } \\
\text { cal roles and } \\
\text { asynchronous } \\
\text { learning net- } \\
\text { works }\end{array}$ & $\begin{array}{l}\text { Journal of } \\
\text { Management } \\
\text { Information } \\
\text { Systems }\end{array}$ & Qualitative & $\begin{array}{l}\text { This paper presents a qualita- } \\
\text { tive study of role changes } \\
\text { that occur when faculty be- } \\
\text { come online or "virtual" pro- } \\
\text { fessors. In } 20 \text { semi-structured } \\
\text { interviews of faculty, coded } \\
\text { with pattern analysis soft- } \\
\text { ware, the authors captured } \\
\text { role changes enacted by in- } \\
\text { structors in ALN settings - } \\
\text { cognitive roles, affective } \\
\text { roles, and managerial roles. } \\
\text { Overall, faculty reported a } \\
\text { change in their teaching per- } \\
\text { sona, toward more precision } \\
\text { in their presentation of mate- } \\
\text { rials and instructions, com- } \\
\text { bined with a shift to a more } \\
\text { Socratic pedagogy, empha- } \\
\text { sizing multilogues with stu- } \\
\text { dents. }\end{array}$ \\
\hline
\end{tabular}




\begin{tabular}{|c|c|c|c|c|}
\hline $\begin{array}{l}\text { Cormier, D., } \\
\text { McAuley, A., } \\
\text { Stewart, B., \& } \\
\text { Siemens, G. } \\
(2010) .\end{array}$ & $\begin{array}{l}\text { The mooc } \\
\text { model for digi- } \\
\text { tal practice }\end{array}$ & Coursera & Qualitative & $\begin{array}{l}\text { The study argues that build- } \\
\text { ing and sustaining prosperity } \\
\text { through Canada's current } \\
\text { digital strengths depends on a } \\
\text { digital ecosystem that em- } \\
\text { braces both infrastructure and } \\
\text { the collaborative social net- } \\
\text { works enabled by that infra- } \\
\text { structure. By exploring the } \\
\text { relationship of MOOCs to } \\
\text { the digital economy in gen- } \\
\text { eral and their potential roles } \\
\text { to prepare citizens for partic- } \\
\text { ipation in that digital econo- } \\
\text { my in particular, it illustrates } \\
\text { one particularly Canadian } \\
\text { model of how these needs } \\
\text { may be addressed. }\end{array}$ \\
\hline $\begin{array}{l}\text { Cox, B., \& } \\
\text { Cox, B. } \\
(2008) .\end{array}$ & $\begin{array}{l}\text { Developing } \\
\text { interpersonal } \\
\text { and group dy- } \\
\text { namics through } \\
\text { asynchronous } \\
\text { threaded dis- } \\
\text { cussions: The } \\
\text { use of discus- } \\
\text { sion board in } \\
\text { collaborative } \\
\text { learning }\end{array}$ & Education & Qualitative & $\begin{array}{l}\text { This study examines discus- } \\
\text { sion board transcripts from } \\
\text { three graduate education } \\
\text { courses. The researchers } \\
\text { analyze interactions between } \\
\text { and among students. Qualita- } \\
\text { tive and quantitative tran- } \\
\text { script content analyses are } \\
\text { conducted to determine that } \\
\text { asynchronous threaded dis- } \\
\text { cussions can be used to cre- } \\
\text { ate a collaborative learning } \\
\text { environment as well as inter- } \\
\text { personal and group dynam- } \\
\text { ics. }\end{array}$ \\
\hline $\begin{array}{l}\text { Crawford- } \\
\text { Ferre, H. G., } \\
\text { \& Wiest, L. } \\
\text { R. (2012). }\end{array}$ & $\begin{array}{l}\text { Effective } \\
\text { online instruc- } \\
\text { tion in higher } \\
\text { education }\end{array}$ & $\begin{array}{l}\text { The Quarterly } \\
\text { Review of Dis- } \\
\text { tance Educa- } \\
\text { tion }\end{array}$ & Qualitative & $\begin{array}{l}\text { This article is a summary of } \\
\text { effective practices in online } \\
\text { instructional methods, in- } \\
\text { cluding course design, inter- } \\
\text { action among course partici- } \\
\text { pants, and instructor prepara- } \\
\text { tion and support. }\end{array}$ \\
\hline
\end{tabular}




\begin{tabular}{|c|c|c|c|c|}
\hline $\begin{array}{l}\text { Finch, D., \& } \\
\text { Jacobs, K. } \\
(2012) .\end{array}$ & $\begin{array}{l}\text { Online educa- } \\
\text { tion: Best prac- } \\
\text { tices to pro- } \\
\text { mote learning }\end{array}$ & $\begin{array}{l}\text { Proceedings of } \\
\text { the Human } \\
\text { Factors and } \\
\text { Ergonomics } \\
56^{\text {th }} \text { annual } \\
\text { meeting }\end{array}$ & Qualitative & $\begin{array}{l}\text { "The purpose of this paper is } \\
\text { to discuss best practices and } \\
\text { the evidence literature related } \\
\text { to online education. High } \\
\text { quality educational experi- } \\
\text { ences in human factors and } \\
\text { ergonomics (HFE) are of in- } \\
\text { terest to the global ergonom- } \\
\text { ics community in order to } \\
\text { promote the development of } \\
\text { the profession, enhance the } \\
\text { skill set of HFE practitioners, } \\
\text { and facilitate the translation } \\
\text { of knowledge into practice } \\
\text { (Dul et al., 2012). }\end{array}$ \\
\hline $\begin{array}{l}\text { Gallagher, S., } \\
\text { LaBrie, J. } \\
(2012) .\end{array}$ & $\begin{array}{l}\text { Online learning } \\
2.0: \text { Strategies } \\
\text { for a mature } \\
\text { market }\end{array}$ & $\begin{array}{l}\text { Continuing } \\
\text { Higher Educa- } \\
\text { tion Review }\end{array}$ & Qualitative & $\begin{array}{l}\text { This article has elucidated } \\
\text { aspects of one institution's } \\
\text { approach to online education } \\
\text { - Northeastern University }\end{array}$ \\
\hline $\begin{array}{l}\text { Garrison, D. } \\
\text { R., Anderson, } \\
\text { T., \& Archer, } \\
\text { W. (2009). }\end{array}$ & $\begin{array}{l}\text { Critical think- } \\
\text { ing, cognitive } \\
\text { presence, and } \\
\text { computer con- } \\
\text { ferencing in } \\
\text { distance educa- } \\
\text { tion }\end{array}$ & $\begin{array}{l}\text { American } \\
\text { Journal of Dis- } \\
\text { tance Educa- } \\
\text { tion }\end{array}$ & Qualitative & $\begin{array}{l}\text { The authors present encour- } \\
\text { aging empirical findings re- } \\
\text { lated to an attempt to create } \\
\text { an efficient and reliable in- } \\
\text { strument to assess the nature } \\
\text { and quality of critical dis- } \\
\text { course and thinking in a text- } \\
\text { based educational context. } \\
\text { The authors suggest that } \\
\text { cognitive presence (i.e., criti- } \\
\text { cal, practical inquiry) can be } \\
\text { created and supported in a } \\
\text { computer-conference envi- } \\
\text { ronment with appropriate } \\
\text { teaching and social presence. }\end{array}$ \\
\hline $\begin{array}{l}\text { Garrison, D. } \\
\text { R., \& Ar- } \\
\text { baugh, J. B. } \\
(2007) \text {. }\end{array}$ & $\begin{array}{l}\text { Researching } \\
\text { the community } \\
\text { of inquiry } \\
\text { framework: } \\
\text { Review, issues, } \\
\text { and future di- } \\
\text { rections }\end{array}$ & $\begin{array}{l}\text { The Internet } \\
\text { and Higher } \\
\text { Education }\end{array}$ & Qualitative & $\begin{array}{l}\text { This literature review exam- } \\
\text { ines recent research pertain- } \\
\text { ing to the overall framework } \\
\text { as well as to specific studies } \\
\text { on social, teaching, and cog- } \\
\text { nitive presence. }\end{array}$ \\
\hline
\end{tabular}




\begin{tabular}{|c|c|c|c|c|}
\hline $\begin{array}{l}\text { Garrison, D. } \\
\text { R., Anderson, } \\
\text { T., \& Archer, } \\
\text { W. (2000). }\end{array}$ & $\begin{array}{l}\text { Critical inquiry } \\
\text { in a text-based } \\
\text { environment: } \\
\text { Computer con- } \\
\text { ferencing in } \\
\text { higher educa- } \\
\text { tion }\end{array}$ & $\begin{array}{l}\text { The Internet } \\
\text { and Higher } \\
\text { Education }\end{array}$ & Qualitative & $\begin{array}{l}\text { The purpose of this study is } \\
\text { to provide conceptual order } \\
\text { and a tool for the use of } \\
\text { computer-mediated commu- } \\
\text { nication (CMC) and comput- } \\
\text { er conferencing in supporting } \\
\text { an educational experience. } \\
\text { Central to the study intro- } \\
\text { duced here is a model of } \\
\text { community inquiry that con- } \\
\text { stitutes three elements essen- } \\
\text { tial to an educational transac- } \\
\text { tion-cognitive presence, } \\
\text { social presence, and teaching } \\
\text { presence. This research sug- } \\
\text { gests that computer confer- } \\
\text { encing has considerable po- } \\
\text { tential to create a community } \\
\text { of inquiry for educational } \\
\text { purposes. }\end{array}$ \\
\hline $\begin{array}{l}\text { Harasim, L. } \\
(2000) .\end{array}$ & $\begin{array}{l}\text { Shift happens: } \\
\text { Online educa- } \\
\text { tion as a new } \\
\text { paradigm in } \\
\text { learning }\end{array}$ & $\begin{array}{l}\text { Internet and } \\
\text { Higher Educa- } \\
\text { tion }\end{array}$ & Qualitative & $\begin{array}{l}\text { Beginning with the innova- } \\
\text { tions of early pioneers as } \\
\text { contributing to the paradig- } \\
\text { matic shift, the study pro- } \\
\text { vides a framework for under- } \\
\text { standing this new field. The } \\
\text { article then focuses on the } \\
\text { Virtual-U, a Web-based envi- } \\
\text { ronment especially custom- } \\
\text { ized to support advanced ed- } \\
\text { ucational practices. }\end{array}$ \\
\hline $\begin{array}{l}\text { Keengwe, J., } \\
\text { \& Kidd, T. T. } \\
(2010) .\end{array}$ & $\begin{array}{l}\text { Towards best } \\
\text { practices in } \\
\text { online learning } \\
\text { and teaching in } \\
\text { higher educa- } \\
\text { tion }\end{array}$ & $\begin{array}{l}\text { MERLOT } \\
\text { Journal of } \\
\text { Online Learn- } \\
\text { ing and Teach- } \\
\text { ing }\end{array}$ & Qualitative & $\begin{array}{l}\text { This article examines a re- } \\
\text { view of literature related to } \\
\text { online learning and teaching. } \\
\text { The authors provide a brief } \\
\text { historical perspective of } \\
\text { online education as well as } \\
\text { describe the unique aspects } \\
\text { of online teaching and learn- } \\
\text { ing. The barriers to online } \\
\text { teaching, the new faculty } \\
\text { roles in online learning envi- } \\
\text { ronments, and some implica- } \\
\text { tions for online learning and } \\
\text { teaching are also provided. }\end{array}$ \\
\hline
\end{tabular}




\begin{tabular}{|c|c|c|c|c|}
\hline Ke, F. (2010). & $\begin{array}{l}\text { Examining } \\
\text { online teach- } \\
\text { ing, cognitive, } \\
\text { and social } \\
\text { presence for } \\
\text { adult students }\end{array}$ & $\begin{array}{l}\text { Computers \& } \\
\text { Education }\end{array}$ & $\begin{array}{l}\text { Mixed- } \\
\text { method }\end{array}$ & $\begin{array}{l}\text { This study examined the na- } \\
\text { ture and interactions of } \\
\text { teaching, cognitive, and so- } \\
\text { cial presence created by } \\
\text { online instructors and adult } \\
\text { students in diverse course } \\
\text { contexts. The study results } \\
\text { indicated online instructional } \\
\text { design and teaching elements } \\
\text { that are crucial prerequisites } \\
\text { for a successful online higher } \\
\text { educational experience for } \\
\text { adult students. }\end{array}$ \\
\hline $\begin{array}{l}\text { Kehrwald, B. } \\
\text { (2008). }\end{array}$ & $\begin{array}{l}\text { Understanding } \\
\text { social presence } \\
\text { in text-based } \\
\text { online learning } \\
\text { environments }\end{array}$ & $\begin{array}{l}\text { Distance Edu- } \\
\text { cation }\end{array}$ & Qualitative & $\begin{array}{l}\text { This article reports on key } \\
\text { aspects of a theory generative } \\
\text { study into social presence in } \\
\text { text based online learning } \\
\text { environments. The focus of } \\
\text { the article is the nature of } \\
\text { social presence as experi- } \\
\text { enced by online learners in } \\
\text { those environments. }\end{array}$ \\
\hline $\begin{array}{l}\text { Kupczynski, } \\
\text { L., Ice, P., } \\
\text { Wiesenmayer, } \\
\text { R., \& } \\
\text { McCluskey, } \\
\text { F. (2010). }\end{array}$ & $\begin{array}{l}\text { Student per- } \\
\text { ceptions of the } \\
\text { relationship } \\
\text { between indi- } \\
\text { cators of teach- } \\
\text { ing presence } \\
\text { and success in } \\
\text { online course }\end{array}$ & $\begin{array}{l}\text { Journal of In- } \\
\text { teractive } \\
\text { Online Learn- } \\
\text { ing }\end{array}$ & $\begin{array}{l}\text { Mixed- } \\
\text { method }\end{array}$ & $\begin{array}{l}\text { This study uses a mixed } \\
\text { methods approach to explore } \\
\text { student perceptions of the } \\
\text { impact of the indicators of } \\
\text { Teaching Presence on their } \\
\text { success in online courses. } \\
\text { Analysis revealed that level } \\
\text { may be a significant factor in } \\
\text { determining which of the } 13 \\
\text { indicators are considered } \\
\text { most critical to success. }\end{array}$ \\
\hline $\begin{array}{l}\text { Maloney- } \\
\text { Krichmar, D., } \\
\text { \& Abras, C. } \\
(2003) .\end{array}$ & $\begin{array}{l}\text { History of } \\
\text { emergence of } \\
\text { online commu- } \\
\text { nities }\end{array}$ & $\begin{array}{l}\text { Encyclopedia } \\
\text { of Community: } \\
\text { From Village to } \\
\text { Virtual World }\end{array}$ & Qualitative & $\begin{array}{l}\text { The chapter described the } \\
\text { history of technology that } \\
\text { supports online communities } \\
\text { and the changes in user popu- } \\
\text { lations, and then outlined } \\
\text { some key research issues. }\end{array}$ \\
\hline
\end{tabular}




\begin{tabular}{|c|c|c|c|c|}
\hline $\begin{array}{l}\text { Mclsaac, M. } \\
\text { S., \& Gun- } \\
\text { awardena, C. } \\
\text { N. (1996). }\end{array}$ & $\begin{array}{l}\text { Distance edu- } \\
\text { cation }\end{array}$ & $\begin{array}{l}\text { Handbook of } \\
\text { research for } \\
\text { educational } \\
\text { communication } \\
\text { and technolo- } \\
\text { gy: A project of } \\
\text { the Association } \\
\text { for Educational } \\
\text { Communication } \\
\text { and Technolo- } \\
\text { gy }\end{array}$ & Qualitative & $\begin{array}{l}\text { This book chapter reviews } \\
\text { the history of distance educa- } \\
\text { tion worldwide. }\end{array}$ \\
\hline $\begin{array}{l}\text { Moore, M., \& } \\
\text { Kearsley, G. } \\
(2012) .\end{array}$ & $\begin{array}{l}\text { Distance edu- } \\
\text { cation: A sys- } \\
\text { tems view of } \\
\text { online learning }\end{array}$ & Wadsworth & / & $\begin{array}{l}\text { The book is researched-based } \\
\text { and grounded in solid princi- } \\
\text { ples of teaching and learning. } \\
\text { The authors apply their broad } \\
\text { experience and expertise as } \\
\text { they explain how to design } \\
\text { and teach courses online-- } \\
\text { including the latest technolo- } \\
\text { gies employed, characteris- } \\
\text { tics of learners, organization- } \\
\text { al structures, and current pol- } \\
\text { icy and global perspectives. }\end{array}$ \\
\hline $\begin{array}{l}\text { Parker, K., } \\
\text { Lenhart, A., } \\
\text { \& Moore, K. } \\
\text { (2011). }\end{array}$ & $\begin{array}{l}\text { The digital } \\
\text { revolution and } \\
\text { higher educa- } \\
\text { tion: College } \\
\text { presidents, } \\
\text { public differ on } \\
\text { value of online } \\
\text { learning }\end{array}$ & $\begin{array}{l}\text { Pew Research } \\
\text { Center }\end{array}$ & Quantitative & $\begin{array}{l}\text { This report is based on find- } \\
\text { ings from a pair of Pew Re- } \\
\text { search Center surveys con- } \\
\text { ducted in spring } 2011 \text {. A } \\
\text { summary of key findings as } \\
\text { follows (1) The Value of } \\
\text { Online Learning; (2) The } \\
\text { Prevalence of Online Cours- } \\
\text { es; (3) Online Students; (4) } \\
\text { The Future of Online Learn- } \\
\text { ing; (5) Digital Textbooks; } \\
\text { (6) The Internet and Plagia- } \\
\text { rism; (7) Do Laptops and } \\
\text { Smartphones Belong in the } \\
\text { Classroom? (8) College Pres- } \\
\text { idents and Technology; and } \\
\text { (9) College Presidents and } \\
\text { Social Networking. }\end{array}$ \\
\hline $\begin{array}{l}\text { Parsad, B., } \\
\text { Lewis, L., } \\
\text { \&Tice, P. } \\
\text { (2008). }\end{array}$ & $\begin{array}{l}\text { Distance edu- } \\
\text { cation at de- } \\
\text { gree-granting } \\
\text { postsecondary } \\
\text { institutions: } \\
\text { 2006-07 }\end{array}$ & $\begin{array}{l}\text { National Center } \\
\text { for Education } \\
\text { Statistics Insti- } \\
\text { tute of Educa- } \\
\text { tion Sciences }\end{array}$ & Quantitative & $\begin{array}{l}\text { This report provides national } \\
\text { estimates on distance educa- } \\
\text { tion at degree-granting post- } \\
\text { secondary institutions in the } \\
2006-07 \text { academic year. }\end{array}$ \\
\hline
\end{tabular}




\begin{tabular}{|c|c|c|c|c|}
\hline $\begin{array}{l}\text { Pelz, B. } \\
\text { (2008). }\end{array}$ & $\begin{array}{l}\text { (My) three } \\
\text { principles of } \\
\text { effective online } \\
\text { pedagogy }\end{array}$ & $\begin{array}{l}\text { Journal of } \\
\text { Asynchronous } \\
\text { Learning Net- } \\
\text { works }\end{array}$ & Qualitative & $\begin{array}{l}\text { Using teaching experiences, } \\
\text { the author examined three } \\
\text { principles of effective online } \\
\text { pedagogy. }\end{array}$ \\
\hline $\begin{array}{l}\text { Rao, K., \& } \\
\text { Tanners, A. } \\
(2011) .\end{array}$ & $\begin{array}{l}\text { Curb cuts in } \\
\text { cyberspace: } \\
\text { Universal in- } \\
\text { structional de- } \\
\text { sign for online } \\
\text { courses }\end{array}$ & $\begin{array}{l}\text { Journal of } \\
\text { Postsecondary } \\
\text { Education and } \\
\text { Disability }\end{array}$ & Qualitative & $\begin{array}{l}\text { This article examines how } \\
\text { principles of Universal In- } \\
\text { structional Design (UID) and } \\
\text { Universal Design for Learn- } \\
\text { ing (UDL) can be incorpo- } \\
\text { rated into an online course to } \\
\text { accommodate an increasingly } \\
\text { diverse body of students in } \\
\text { postsecondary institutions. }\end{array}$ \\
\hline $\begin{array}{l}\text { Saba, F. } \\
\text { (2012). }\end{array}$ & $\begin{array}{l}\text { A systems ap- } \\
\text { proach to the } \\
\text { future of dis- } \\
\text { tance education } \\
\text { in colleges and } \\
\text { universities: } \\
\text { Research, de- } \\
\text { velopment, and } \\
\text { implementation }\end{array}$ & $\begin{array}{l}\text { Continuing } \\
\text { Higher Educa- } \\
\text { tion Review }\end{array}$ & Qualitative & $\begin{array}{l}\text { The author analyzed the re- } \\
\text { search, development and im- } \\
\text { plementation of distance ed- } \\
\text { ucation through a system ap- } \\
\text { proach. }\end{array}$ \\
\hline $\begin{array}{l}\text { Sadera, W. } \\
\text { A., Robert- } \\
\text { son, J., Song, } \\
\text { L., \& Midon, } \\
\text { M. N. (2009). }\end{array}$ & $\begin{array}{l}\text { The role of } \\
\text { community in } \\
\text { online learning } \\
\text { success }\end{array}$ & $\begin{array}{l}\text { Journal of } \\
\text { Online Learn- } \\
\text { ing and Teach- } \\
\text { ing }\end{array}$ & Quantitative & $\begin{array}{l}\text { The purpose of this paper is } \\
\text { to report on the findings of a } \\
\text { study examining the relation- } \\
\text { ships between community } \\
\text { and student success in online } \\
\text { learning. The study was con- } \\
\text { ducted on undergraduate stu- } \\
\text { dents enrolled in online } \\
\text { courses at an accredited uni- } \\
\text { versity on the east coast of } \\
\text { the U.S. Results of the study } \\
\text { indicate a strong correlation } \\
\text { between learner interaction } \\
\text { and engagement, sense of } \\
\text { community, and success in } \\
\text { online learning. }\end{array}$ \\
\hline $\begin{array}{l}\text { Schroeder, R. } \\
\text { (2012). }\end{array}$ & $\begin{array}{l}\text { Emerging open } \\
\text { online distance } \\
\text { education envi- } \\
\text { ronment }\end{array}$ & $\begin{array}{l}\text { Continuing } \\
\text { Higher Educa- } \\
\text { tion Review }\end{array}$ & Qualitative & $\begin{array}{l}\text { The article examines the de- } \\
\text { velopment of Massive Open } \\
\text { Online Classes (MOOC). }\end{array}$ \\
\hline
\end{tabular}




\begin{tabular}{|c|c|c|c|c|}
\hline $\begin{array}{l}\text { Sher, A. } \\
\text { (2009). }\end{array}$ & $\begin{array}{l}\text { Assessing the } \\
\text { relationship of } \\
\text { student- } \\
\text { instructor and } \\
\text { student-student } \\
\text { interaction to } \\
\text { student learn- } \\
\text { ing and satis- } \\
\text { faction in Web- } \\
\text { based Online } \\
\text { Learning Envi- } \\
\text { ronment }\end{array}$ & $\begin{array}{l}\text { Journal of In- } \\
\text { teractive } \\
\text { Online Learn- } \\
\text { ing }\end{array}$ & Quantitative & $\begin{array}{l}\text { This study shows the im- } \\
\text { portance of interaction to } \\
\text { student learning within Web- } \\
\text { based online learning pro- } \\
\text { grams. Regression analyses } \\
\text { were employed to analyze } \\
\text { the relationship of interaction } \\
\text { variables with student learn- } \\
\text { ing and satisfaction. Student- } \\
\text { instructor interaction and } \\
\text { student-student interaction } \\
\text { were found to be significant } \\
\text { contributors of student learn- } \\
\text { ing and satisfaction. }\end{array}$ \\
\hline $\begin{array}{l}\text { Shea, P.A., } \\
\text { Swan, K., Li, } \\
\text { C. S., \& } \\
\text { Pickett, A. } \\
(2005) .\end{array}$ & $\begin{array}{l}\text { Developing } \\
\text { learning com- } \\
\text { munity in } \\
\text { online asyn- } \\
\text { chronous col- } \\
\text { lege courses: } \\
\text { The role of } \\
\text { teaching pres- } \\
\text { ence }\end{array}$ & $\begin{array}{l}\text { Journal of } \\
\text { Asynchronous } \\
\text { Learning Net- } \\
\text { works }\end{array}$ & Quantitative & $\begin{array}{l}\text { This paper builds on the } \\
\text { model developed by the au- } \\
\text { thors for creating quality } \\
\text { online learning environments } \\
\text { for higher education. In this } \\
\text { paper two components were } \\
\text { focused on - teaching pres- } \\
\text { ence and community. The } \\
\text { authors argue that learning is } \\
\text { social in nature and that } \\
\text { online learning environments } \\
\text { can be designed to reflect and } \\
\text { leverage the social nature of } \\
\text { learning. }\end{array}$ \\
\hline
\end{tabular}




\begin{tabular}{|c|c|c|c|c|}
\hline $\begin{array}{l}\text { Shea, P., \& } \\
\text { Bidjerano, T. } \\
\text { (2009). }\end{array}$ & $\begin{array}{l}\text { Community of } \\
\text { inquiry as a } \\
\text { theoretical } \\
\text { framework to } \\
\text { foster "epis- } \\
\text { temic engage- } \\
\text { ment" } \\
\text { and "cognitive } \\
\text { presence" in } \\
\text { online educa- } \\
\text { tion }\end{array}$ & $\begin{array}{l}\text { Computer and } \\
\text { Education }\end{array}$ & Quantitative & $\begin{array}{l}\text { The research results indicate } \\
\text { that the survey items cohere } \\
\text { into interpretable factors that } \\
\text { represent the intended con- } \\
\text { structs. Further it was deter- } \\
\text { mined through structural } \\
\text { equation modeling that } 70 \% \\
\text { of the variance in the online } \\
\text { students' levels of cognitive } \\
\text { presence, a multivariate } \\
\text { measure of learning, can be } \\
\text { modeled based on their re- } \\
\text { ports of their instructors' } \\
\text { skills in fostering teaching } \\
\text { presence and their own abili- } \\
\text { ties to establish a sense of } \\
\text { social presence. Additional } \\
\text { analysis identifies more de- } \\
\text { tails of the relationship be- } \\
\text { tween learner understandings } \\
\text { of teaching and social pres- } \\
\text { ence and its impact on their } \\
\text { cognitive presence. }\end{array}$ \\
\hline $\begin{array}{l}\text { Short, J., Wil- } \\
\text { liams, E., \& } \\
\text { Christie, B. } \\
\text { (1976). }\end{array}$ & $\begin{array}{l}\text { The social psy- } \\
\text { chology of } \\
\text { communication }\end{array}$ & John Wiley & I & $\begin{array}{l}\text { The book investigated the } \\
\text { use of telephone and other } \\
\text { electronically mediated } \\
\text { communication in the early } \\
1970 \text { s and examined com- } \\
\text { munication that occurred in } \\
\text { the absence of non-verbal } \\
\text { communication. The authors } \\
\text { found that different media } \\
\text { allowed varied levels of so- } \\
\text { cial presence. }\end{array}$ \\
\hline
\end{tabular}




\begin{tabular}{|c|c|c|c|c|}
\hline $\begin{array}{l}\text { Swan, K., } \\
\text { Garrison, } \\
\text { D.R., \& Rich- } \\
\text { ardson, J. } \\
(2009) .\end{array}$ & $\begin{array}{l}\text { A constructiv- } \\
\text { ist approach to } \\
\text { online learn- } \\
\text { ing: The com- } \\
\text { munity of } \\
\text { inquiry frame- } \\
\text { work }\end{array}$ & $\begin{array}{l}\text { Information } \\
\text { Technology } \\
\text { and Construc- } \\
\text { tivism in High- } \\
\text { er Education: } \\
\text { Progressive } \\
\text { Learning } \\
\text { Frameworks }\end{array}$ & Qualitative & $\begin{array}{l}\text { This chapter presents a theo- } \\
\text { retical model of online learn- } \\
\text { ing, the Community of In- } \\
\text { quiry (CoI) framework, } \\
\text { which is grounded in John } \\
\text { Dewey's progressive under- } \\
\text { standing of education. The } \\
\text { CoI framework is a process } \\
\text { model of online learning } \\
\text { which views the online edu- } \\
\text { cational experience as arising } \\
\text { from the interaction of three } \\
\text { presences - social presence, } \\
\text { cognitive presence, and } \\
\text { teaching presence. }\end{array}$ \\
\hline $\begin{array}{l}\text { Tallent- } \\
\text { Runnels, M. } \\
\text { K., Thomas, } \\
\text { J. A., Lan, W. } \\
\text { Y., Cooper, } \\
\text { S., Ahern, T. } \\
\text { C., Shaw, S. } \\
\text { M., \& Liu, X. } \\
\text { (2006). }\end{array}$ & $\begin{array}{l}\text { Teaching } \\
\text { courses online: } \\
\text { A review of the } \\
\text { research }\end{array}$ & $\begin{array}{l}\text { Review of Edu- } \\
\text { cational Re- } \\
\text { search }\end{array}$ & Qualitative & $\begin{array}{l}\text { This literature review sum- } \\
\text { marizes research on online } \\
\text { teaching and learning. The } \\
\text { authors found little con- } \\
\text { sistency of terminology, dis- } \\
\text { covered some conclusive } \\
\text { guidelines, and identified } \\
\text { developing lines of inquiry. } \\
\text { The conclusions overall sug- } \\
\text { gest that most of the studies } \\
\text { reviewed were descriptive } \\
\text { and exploratory, that most } \\
\text { online students are nontradi- } \\
\text { tional and Anglo American, } \\
\text { and that few universities } \\
\text { have written policies, guide- } \\
\text { lines, or technical support for } \\
\text { faculty members or students. }\end{array}$ \\
\hline $\begin{array}{l}\text { Wallace, R. } \\
(2003) \text {. }\end{array}$ & $\begin{array}{l}\text { Online learn- } \\
\text { ing in higher } \\
\text { education: A } \\
\text { review of re- } \\
\text { search on in- } \\
\text { teractions } \\
\text { among teachers } \\
\text { and students }\end{array}$ & $\begin{array}{l}\text { Education, } \\
\text { Communication } \\
\text { \& Information }\end{array}$ & Qualitative & $\begin{array}{l}\text { The purpose of this article is } \\
\text { to provide an overview of the } \\
\text { existing literature in commu- } \\
\text { nications, distance education, } \\
\text { educational technology, and } \\
\text { other education-related } \\
\text { fields. The review indicates } \\
\text { that, although there has been } \\
\text { extensive work to conceptu- } \\
\text { alize and understand the so- } \\
\text { cial interactions and con- } \\
\text { structs entailed by online ed- } \\
\text { ucation, there has been little } \\
\text { work that connects these } \\
\text { concepts to subject-specific } \\
\text { interactions and learning. }\end{array}$ \\
\hline
\end{tabular}




\begin{tabular}{|l|l|l|l|l|}
\hline $\begin{array}{l}\text { Wang, Y. D. } \\
\text { (2014). }\end{array}$ & $\begin{array}{l}\text { Building stu- } \\
\text { dent trust in } \\
\text { online learning } \\
\text { environments }\end{array}$ & $\begin{array}{l}\text { Distance Edu- } \\
\text { cation }\end{array}$ & Quantitative & $\begin{array}{l}\text { The study represents an at- } \\
\text { tempt to address the chal- } \\
\text { lenge by identifying the so- } \\
\text { cial and technical factors that } \\
\text { can likely induce or influence } \\
\text { students perception about } \\
\text { the trustworthiness of an } \\
\text { online course and integrating } \\
\text { the factors into a socio- } \\
\text { technical framework that can } \\
\text { be empirically validated. }\end{array}$ \\
\hline $\begin{array}{l}\text { Whipp, J. L., } \\
\text { \& Lorentz, E. } \\
\text { R. A. (2009). }\end{array}$ & $\begin{array}{l}\text { Cognitive and } \\
\text { social help giv- } \\
\text { ing in online } \\
\text { teaching: An } \\
\text { exploratory } \\
\text { study }\end{array}$ & $\begin{array}{l}\text { Educational } \\
\text { Technology } \\
\text { Desearch and }\end{array}$ & Qualitative & $\begin{array}{l}\text { In this study, the authors } \\
\text { used theories and research on } \\
\text { learning assistance and scaf- } \\
\text { folding, teacher immediacy, } \\
\text { social presence, and academ- } \\
\text { ic help seeking to explore } \\
\text { through a cross-case study } \\
\text { design how three online in- } \\
\text { structors differed in their use } \\
\text { of cognitive and social sup- } \\
\text { ports and how those differ- } \\
\text { ences related to student per- } \\
\text { ceptions of support, help } \\
\text { seeking, and performance. }\end{array}$ \\
\hline
\end{tabular}




\begin{tabular}{|c|c|c|c|c|}
\hline $\begin{array}{l}\text { Yang, J., Yu, } \\
\text { H., Chen, S. } \\
\text { J., \& Huang, } \\
\text { R. (2014). }\end{array}$ & $\begin{array}{l}\text { Strategies for } \\
\text { Smooth and } \\
\text { Effective } \\
\text { Cross-Cultural } \\
\text { Online } \\
\text { Collaborative } \\
\text { Learning }\end{array}$ & $\begin{array}{l}\text { Educational } \\
\text { Technology \& } \\
\text { Society }\end{array}$ & Qualitative & $\begin{array}{l}\text { The purpose of the study is to } \\
\text { elicit strategies for smooth } \\
\text { and effective cross-cultural } \\
\text { online collaborative learning } \\
\text { through a pilot study between } \\
\text { the West and the East. Stu- } \\
\text { dents of a Chinese University } \\
\text { and an American University } \\
\text { took part in the study. The } \\
\text { findings of the study revealed } \\
\text { that students from both sides } \\
\text { were interested in each oth- } \\
\text { er's culture, their attitudes to } \\
\text { cross-cultural online collabo- } \\
\text { rative learning were positive, } \\
\text { and culture had an influence } \\
\text { on learning methods. }\end{array}$ \\
\hline $\begin{array}{l}\text { Yuan, J., \& } \\
\text { Kim, C. } \\
(2014) .\end{array}$ & $\begin{array}{l}\text { Guidelines for } \\
\text { facilitating the } \\
\text { development of } \\
\text { learning com- } \\
\text { munities in } \\
\text { online courses }\end{array}$ & $\begin{array}{l}\text { Journal of } \\
\text { Computer As- } \\
\text { sisted Learning }\end{array}$ & Qualitative & $\begin{array}{l}\text { In this paper, the authors } \\
\text { propose guidelines for online } \\
\text { instructors to facilitate the } \\
\text { development of learning } \\
\text { communities in online cours- } \\
\text { es. They first review the def- } \\
\text { inition of a learning commu- } \\
\text { nity, importance of a learning } \\
\text { community and factors af- } \\
\text { fecting the development of a } \\
\text { learning community. After- } \\
\text { wards, based on a review of } \\
\text { the existing guidelines and } \\
\text { other relevant literature, they } \\
\text { propose guidelines for facili- } \\
\text { tating the development of } \\
\text { learning communities in } \\
\text { online courses }\end{array}$ \\
\hline
\end{tabular}

\section{Biographies}

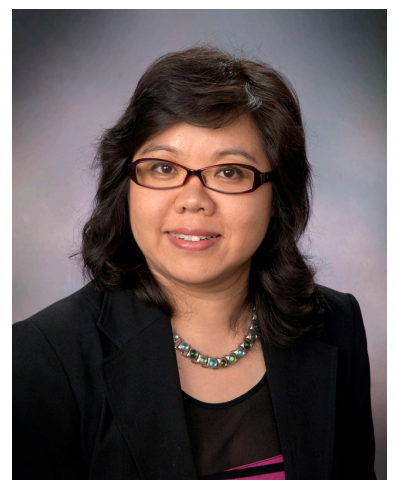

Dr. Anna Q. Sun is an Assistant Professor of the Department of Educational Services and Leadership in the College of Education at Rowan University. She received her Ph.D. in Educational Leadership and Administration and the Ed. M. in General Education with a specialization in Comparative and Global Studies in Education from the State University of New York at Buffalo (SUNY), and the B.A. in Teaching English As A Foreign Language from Tianjin Teachers' College. Dr. Sun's ongoing scholarship and research include online education for educational leadership preparation programs, educational leadership and policies, social justice in schools, and international development and studies in education. She has published numerous refereed journal 
articles, book, book chapters, and conference presentations at national and international conferences such as the annual conferences of AERA, UCEA, and CIES. A recipient of grants of Mark Diamond Research Fund and AERA Foster-Polite scholarship, Dr. Sun is an active member and contributor in AERA, UCEA, and CIES. Dr. Sun has served as the Plenary Session Representative of the University Council for Educational Administration, manuscript reviewers for Journal of Educational Administration, Leadership and Policy in Schools, and International Journal of Educational Administration, and conference proposal reviewers for AERA, UCEA, and CIES annual conferences. At Rowan, she teaches educational leadership and administration courses at the graduate level.

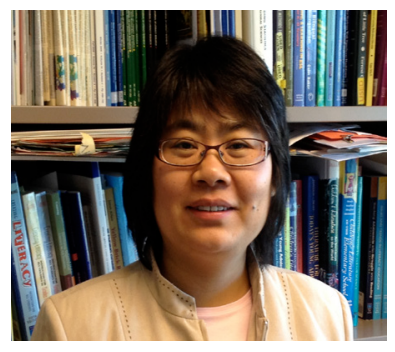

Dr. Xiufang Chen is currently an Associate Professor of Language and Literacy Education in the College of Education at Rowan University. She received her Ph.D. in Curriculum and Instruction with a specialization in Language and Literacy Education from Texas Tech University, M.A. in Teaching English as a Foreign Language from Beijing Normal University, and B.A. in English Education from Qufu Normal University, China. Her current research interests include social-cultural dimensions of literacy learning, multicultural education through literature, English language learners, and online education. She has published numerous refereed journal articles, book chapters and conference presentations at national and international conferences such as the annual conferences of AERA, LRA, IRA, and NCTE. Some of her projects have been funded by the NSF, Buid-A-Bear Workshop Foundation, Christian R \& Mary F. Lindback Foundation, and Rowan University's Innovations in Teaching Using Technology and SEED

Grants. Dr. Chen has served on the Editorial Review Board of the Literacy Research Association Yearbook and the LRA Technology Standing Committee. She is also a manuscript reviewer for Action in Teacher Education, The Reading Teacher, and a conference proposal reviewer for the LRA and AERA annual conferences. At Rowan, she teaches literacy education courses at both the Graduate and Undergraduate levels. 